\title{
Seçmen Kararlarında Duyguların Rolü ve İşlevi: Duygusal Iç̧erikli Reklamlar Üzerine Bir Analiz
}

\section{Mustafa Akdağ, Merve Özdemir}

\section{ÖZ}

Demokrasinin egemen olduğu birçok ülkede seçim uygulaması büyük bir rol oynamaktadır. Iktidara gelmeyi hedefleyen her parti, seçim uygulamalarında seçmeni etkileyecek iletişim stratejileri geliştirmektedir. Geçmişten bu yana seçmen davranışını anlamaya çalışanlar, seçmenin rasyonel tercihler doğrultusunda karar verme ve seçme işlemini gerçekleştirdiğini belirtse de son dönemde insan davranışını anlamaya çalışan birçok çalışma davranışların sadece mantıksal düzlemde ele alınamayacağını, duygusal faktörlerin de derinlemesine araştırılması gerektiğini ortaya çıkarmaktadır. 1950'li yıllardan itibaren yapılan birçok araştırma seçmenin politik kararlarında tamamen mantıksal çıkarımlarda bulunmadığını ve duygusal olarak etkilenme güdüsünün çok daha yüksek olduğunu ortaya koymaktadır. Bu doğrultuda davranış örüntüsü geliştiren seçmen, seçim kampanyalarında bilinçli ya da bilinçsiz olarak duygusal iletişim stratejilerinden etkilenebilmektedir. Buradan hareketle çalışmada, duygu kavramına literatürde geniş bir yer verilerek seçmen davranışlarını açıklamada duyguların oynadığı rol ve işlevler detaylı bir şekilde açıklanacaktır. Özellikle siyasal iletişim boyutunda AK Parti ve CHP'nin Yerel ve Genel Milletvekili Seçimleri ile Cumhurbaşkanlığı Seçim reklamları duygu faktörünün nasıl kodlandığı ve uygulandığı açısından nitel araştırma yöntemi ile analiz edilecektir. Bu bağlamda her iki partinin iki farklı reklamı nitel analiz yöntemi içerisinde bulunan içerik analizi ve betimsel analiz yöntemi ile incelenecek tir. Betimsel analiz yöntemi, çalışmadaki verilerin sınıflandırılması, özetlenmesi ve sonuçlara ulaşılmasını sağlarken, içerik analizi yöntemi ise reklamların karakterize edilmesi, sınıflandırılması ve yorumlanması amacıyla kullanılacaktır. Bu sonuçlara göre siyaset, iletişim ve duygu kavramları arasındaki ilişki ortaya çıkarılacak, seçmenin duygusal etkilere açık oluşu literatür çerçevesinde değerlendirilecektir.

Anahtar Sözcükler: Siyaset, Iletişim, Siyasal Iletişim, Duygular, Partiler

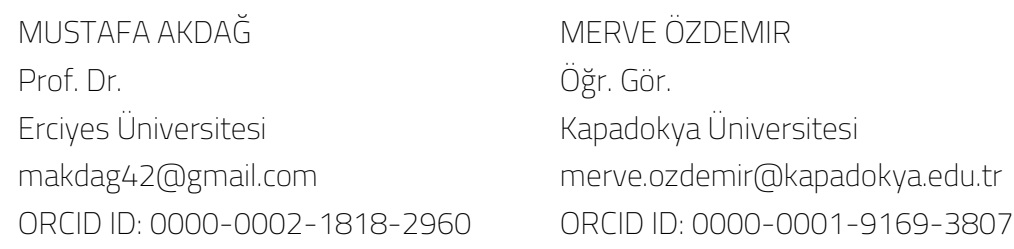

SELÇUK ILETIŞIM DERGISI 2021; 14(2): 895-926

doi: 10.18094/ JOSC.882765

Geliş Tarihi: 18.02.2021 Kabul Tarihi: 24.03.2021 Yayın Tarihi: 25.04.2021 
The Role and Function of Emotions in Voter Decisions: An Analysis on
Emotional Advertisements
JOURNAL OF SELÇUK COMMUNICATION 2021; $14(2): 895-926$

doi: 10.18094/ JOSC.882765

\author{
Mustafa Akdağ, Merve Özdemir
}

\begin{abstract}
In many countries where democracy is dominant, election practice plays a big role. Every party that aims to come to power develops communication strategies that will affect the voters in election practices. Although many names who have tried to understand voter behavior since the past have stated that voters perform the decision-making and selection process in line with rational preferences, many studies trying to understand human behavior have recently revealed that behaviors cannot be dealt with only on a logical plane, and their emotional factors should be investigated in depth. Many studies since the 1950s have revealed that the voters do not make logical inferences in their political decisions and that the motivation to be emotionally affected is much higher. Voters who develop a behavioral pattern in this direction are consciously or unconsciously affected by emotional communication strategies during election campaigns. From this point of view, the concept of emotion will be given a wide place in the literature and the role and functions of emotions in explaining voter behavior will be explained in detail throughout the study. Especially in the political communication dimension, the advertisements of AK Party and CHP in the local, presidential and presidential elections will be analyzed with qualitative research method.
\end{abstract}

Keywords: Politics, Communication, Political Communication, Emotions, Parties

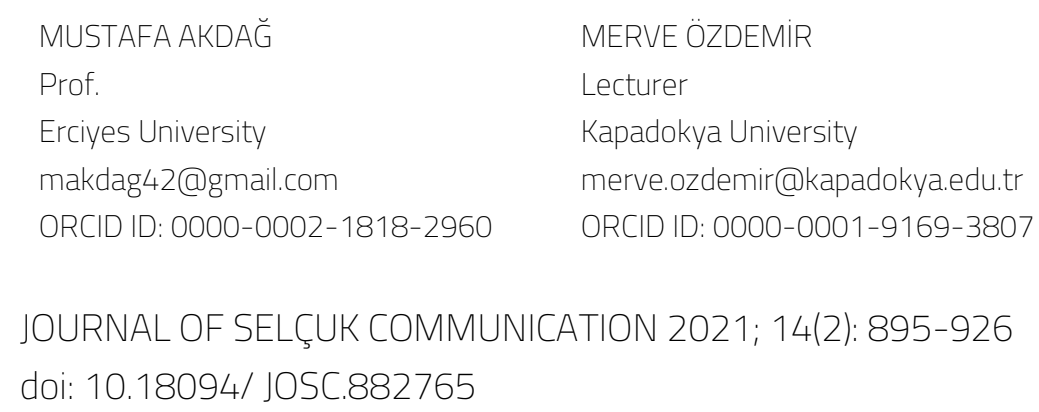

\author{
MERVE ÖZDEMIR \\ Lecturer \\ Kapadokya University \\ merve.ozdemir@kapadokya.edu.tr \\ ORCID ID: 0000-0001-9169-3807
}




\section{Gíriş}

Günümüzde seçmen davranışlarını yönlendirmeye çalışan siyasi liderlerin hem rasyonel hem de duygusal iletişim stratejileri kullandıkları bilinen bir gerçektir. Seçmenlerin karar alma süreçlerinde sadece rasyonel faktörlerin değil duygusal faktörlerin de oldukça işlevsel olduğu bilimsel olarak da kanıtlanmaktadır. Seçmen duygularını yönlendirerek iktidarın lehine kullanma düşüncesi her ne kadar eski dönemlere dayansa da son dönemde insan beyni üzerine yapılan birçok bilimsel araştırma, bu stratejilerin kullanılmasını daha da derinleştirmekte ve etkili bir boyuta taşımaktadır.

Siyasi partiler, liderler, mesaj stratejileri, vaatler, parti programları gibi siyasal bilgiye ihtiyaç duyması seçmenin karar verirken kanaatlerini oluşturmada önemli bir yere sahiptir (Özkan, 2015, s. 7). Seçmenin ihtiyaç duyduğu tüm bu bilgilerin belirli ikna stratejisi ile oluşturulması, rasyonel ve duygusal mesaj stratejilerinin önemini de ortaya koymaktadır. Bu anlamda oluşturulacak olan siyasal iletişim stratejilerinde seçmenin tutumu, bilişsel haritası ve inanç sistemleri duygusal mesajın kodlanmasında kullanılan temel bileşenler arasında yer almaktadır. Bazı görüşlere göre, her ne kadar seçmenin politik karar verme süreçlerinde rasyonel karar alma mekanizmasını aktif olarak kullandığı belirtilse de duygu üzerine yapılan çalışmalar bu durumun daha öncelikli bir şekilde gerçekleştiğini ortaya koymaktadır. Bunun yanında seçmenin her zaman bilgiyi doğru bir şekilde değerlendirememesi onun duyguları ve tepkileri ile hareket ettiğini de göstermektedir. Bireylerin tamamen rasyonel tercihlerle karar verememesinin başında yer alan; kültür, geçmiş deneyimler, çevresel koşullar, sosyo-ekonomik seviye, toplumsal norm ve kurallar, iktidar yapısı gibi temel faktörler, karar alma tercihlerinde çok fazla verinin bir arada olduğunu göstermektedir. Bu bahsedilen faktörlerin bireyin fenomen alanına etki etmesi politik karar verme süreçlerini de doğal olarak tamamen rasyonel bir halde değerlendirememesine sebep olmaktadır. Yine seçmenin aday sempatisi ve partiyle özdeşleşmesi gibi düşünsel ve davranışsal çıktıları kişinin bir görüşe, partiye veya lidere duygusal bağlarla bağı olduğunu desteklemektedir.

Duygular, seçmenlerin etkilenmesinde kitle iletişim araçlarının rolünü ve gücünü de ortaya koymaktadır. Siyasal iletişimin odak noktası olan kitle iletişim araçları, seçim kampanyalarının teknik ve yöntemlerini de geliştirip dönüştürmektedir. Bu bağlamda siyasi liderlerin seçmene direkt olarak kitle iletişim araçları ile ulaşıyor olması, oluşturulan toplumsal dönüşümünde mesaj stratejilerine yansımasını gerekli kılmaktadır. Bu sebeple konu içerisinde de ele alınan bireyin duygusal boyutundaki değişimler, 
toplumsal haraketlilik içerisinde takip edilmekte ve siyasal iletişim stratejileri de kurgulanmaktadır. Çalışma boyunca duygunun da rasyonel karar alma süreci kadar seçmeni etkilediği hem yapılan literatür hem de araştırma kısmında ortaya konulmaktadır. Çalışma içerisindeki siyasal reklamlarda da görüldüğü üzere en çok kodlanan duygusal mesajların bireylerde belli duygu yüklerini ortaya çıkarmayı amaçladığı ve bu yolda başarıya ulaşmayı hedeflediği gözlemlenmektedir.

\section{DUYGU KAVRAMINA GENEL BIR BAKIŞ}

İnsan üzerine düşünmenin ve onu anlamanın bir parçası olarak araştırılan duygu kavramı, tarihten bu yana birçok disiplin tarafından araştırma konusu haline gelmektedir. İnsan beyninin karmaşık bir yapıdan oluşması ve geçmişten günümüze dek hala tam anlamı ile çözülememiş olması (Batı, 2018), bireylerin kararlarında hem bilişsel hem de duygusal faktörlerin birlikte ele alınması gerektiğini ortaya koymaktadır. Özellikle bireylerin karar alma davranışlarında sadece rasyonel süreçlerin etkili olmadığı, aynı zamanda duygu faktörünün de oldukça önemli bir yere sahip olduğu bilinen bir gerçektir. Bu durum zihnin işleyişini karmaşık bir hale getirirken, davranışların da genellenemeyecek ölçüde bireysel olduğunu ifade etmektedir (Damasio, 2018, s. 30). Loewenstein'a göre "Beynin büyük bölümü bilinçli düşünmekten çok, otomatik süreçlerin etkisi altındadır. Bu nedenle beyinde gerçekleşen işlemlerin çoğu düşünerek değil, duyguların etkisi altında gerçekleşmektedir" (Akt. Batı, 2020, s. 172). Özellikle günümüzde siyaset, psikoloji, sosyoloji ve iletişim alanındaki birç̧ok düşünür, insanların artık duyguların etkisi altında karar verdiklerini ve düşünmenin ötesinde daha çok duygusal refleksler gösterdiğini savunmaktadır (Batı, 2020, s. 172).

"Bir his ve bu hisse özgü psikolojik, sosyolojik ve biyolojik hallerin etki ettiği bir hareket eğilimi" olarak ifade edilen (Goleman, 2004, s. 359) duygu, Damasio'ya göre dış dünyaya, başka kişilere görünüp yüzde, konuşmada ve belli başı olaylarda kendini gösteren eylem ve hareketler olarak ele alınabilmektedir $(2018$, s. 30)

Duygu kavramı, bilinen beş somut insan duyusunun altıncısını oluşturmaktadır. Bu sebeple dünyayı bilmenin sadece beş duyu organından ibaret olmadığını ve duygunun kişisel algılamada oldukça farklı yansımalar gösterdiğini ifade etmek mümkündür. Duygu duyusu, beş duyu organdan çok farklı bir şekilde örgütlenmektedir. Bunun temel sebebi ise bir ölçüde belli bir kanala bağlı işlevden çok, duruma bağı bir işlevi gerçekleştirmesidir. Bunun yanında duygular oldukça içsel bir süreci ifade etmekte ve bu 
sebeple duygu, sadece kişinin kendisine özel bir durum olarak ortaya çıkmaktadır (Solms \& Turnbull, 2015, s. 109-110).

Duygu, gözle görünmez bir duruma karşılık gelse de esasen hormonel tahliller ve elektrofizyolojik dalga paternleri gibi bilimsel yöntemler sayesinde görünür kılınabilmektedir (Damasio, 2018, s. 30). Beynin duygu üreten sistemlerinin çekirdeğini oluşturan yapılar, arka planda bilinç durumunu meydana getirenlerle aynıdır. Dolayısıyla insanın bilinçli hareketini şekillendiren fonksiyonlar hem bilişsel hem duygusal çıktılar sonucunda gerçekleşmektedir. Bu anlamda duyguların çıktılarını hem içsel hem de dışsal yönelimli bir şekilde gözlemlemek mümkündür. İçeriye yönelik duyguların gösterimini hormonların salgılanması, solunum, kalp atımındaki değişmeler, damarların genişlemesi ve daralması, bölgesel kan akımındaki değişmeler olarak ifade etmek mümkünken, dışarıya yönelik duygu gösterimlerini ise yüz ifadesinde meydana gelen değişmeler, diş gösterme, ağlama, kızarma, saldırganlık, bağırmak olarak ifade etmek mümkündür (Solms \& Turnbull, 2015, s. 111-114). Bu bağlamda kişinin fiziksel ya da maddesel yüzünü temsil eden bu duygular, ancak kişinin kendini izlemesi sonucunda fark edilebilir bir özelliğe sahip olmaktadır (Tolle, 2001, s. 45). Bu anlamda insan duyguları beynin karar vermek için ihtiyaç duyduğu temel yakıttır (Morin \& Renvoise, 2019, s. 127).

Antik Yunan'dan günümüze dek birçok araştırmacı duyguları, hoş olan ve olmayan durumlara karşı geliştirilen bir form olarak ifade etmektedir. Diğer yandan bazı duygusal sınıflandırmaların ise pozitif ve negatif etkiler olarak adlandırıldığını söylemek mümkündür (Barrett \& Russell, 1999, s. 10-11). Duygular; arka plan duygular, birincil duygular ve sosyal duygular olmak üzere üç şekilde sınıflandırılmaktadır. Arka plan duygularda ifade edilen temelde kişinin fiziksel görünümündeki duyguların yanı sıra arka planda kalan duygulara da odaklanabilmektir. Örneğin; bir kişinin konuşurken yalnızca söylediği sözcüklere ve yüzündeki ifadelere değil, ses tonundaki tınıya, sesin güçlü ve zayıf olmasına ya da yüzündeki ifadenin belli bir süre içerisinde nasıl değişkenlik gösterdiğine de dikkat etmektir. Birincil duygular ise her kültürde belli başlı kabul edilen ortak duygu süreçlerini ifade etmektedir (Damasio, 2018, s. 44-47). Bu duygular temelde: Öfke, üzüntü, korku, zevk, sevgi, şaşkınlık ve iğrenmedir (Goleman, 2004, s. 359-360). Son olarak sosyal duygular ise sempati, utanma, ayıp, suçluluk, gurur, kıskançıłık, minnettarlık, içerleme, hor görme kavramlarını içerisinde barındırmaktadır. Burada kavramın sosyal olarak tanımlanması bireyin doğumdan sonraki sürecini ifade etmektedir. Freud'un da belirttiği 
gibi birey, yaşamı boyunca karşı karşıya olduğu insan grupları, nesneler, etkinlikler ve mekanlara göre duygusal olarak belli yakınlık ve uzaklık ilişkisi geliştirmektedir. Örneğin; insanın yaşamı boyunca iç içe olduğu iktidar ilişkileri insanın algı dünyasında bazı kişilerin lider, bazılarının takipçi, bazılarının ise takip edilmesi gerektiği durumunu ön plana çıkarmaktadır (Damasio, 2018, s. 50). Bu doğrultuda ortaya çıkan sosyalleşme ilişkileri bireyin duygusal yaşamını büyük ölçüde etkileyerek karar verme ve davranış geliştirmesinde psikolojik süreçlerin yanı sıra sosyalleşmenin de etkisini ortaya koymaktadır.

İnsanın uyum sürecinde önemli bir uyarıcı olan iktidar ise insan duygularının yönlendirilmesinde başat rol oynamaktadır. Bu bağlamda iktidar tarafından sıklıkla duygusal manipülasyona maruz kalan birey, siyasal karar alma süreçlerinde duygusal yoğunluğun etkisi altında eylemlerini gerçekleştirmektedir. Çalışmanın da ana konusunu oluşturan insan davranışı ve iktidar konusu yönetilen konumundaki bireyin duygusal anlamda yönlendirilişini ön planda tutmayı hedeflemektedir.

\section{KLASIK SIYYSET FELSEFESINDE DUYGU ARAȘTIRMALARI}

Geçmişten günümüze dek birçok filozof ve siyaset bilimci, duyguları siyasetin önemli bir boyutu olarak kabul etmektedir. Duygusal yüklenimlerin ağırlık kazandığı siyasal retorik, siyasal iletişim stratejileri, milliyetçi ve popülist hareketlerin küresel yükselişi, duygular üzerine her geçen gün daha da eğilim gösterildiğini ortaya koymaktadır (Szanto \& Slaby, 2020, s. 1). Özellikle seçmen yapısındaki duygusal bileşenlerin keşfi, siyasetçilerin iletişim stratejilerini büyük ölçüde etkilemektedir. Seçmen kitlesinin tutumu, bilişsel haritası, inanç sistemi ve toplumsal öğretilerinin bu noktada deşifre edilmesi, politika ile ilgilenen herkese önemli veriler sunmakta (Marcus, 1991, s. 196) ve seçim kampanyalarını başarıya ulaştırmaktadır. Bu sebeple geçmişten günümüze kadar insanı anlamak üzerine kurulan tüm disiplinler, insan duygularına da büyük ölçüde önem vermektedir.

İnsan duyguları üzerine yapılan araştırmaların Antik Yunan'a kadar uzandığını söylemek mümkündür. Bu dönemde Stoacılar, bir tutkunun ilk izlerini fark edebilirlerse onu daha iyi kontrol edebileceğini düşünmüşlerdir (Smith, 2018, s. 23-24). Bu sebeple duyguları kontrol etme ve onları istenildiği şekilde yönlendirme arzusu, yöneten ve yönetilen ilişkisini değerlendirmek açısından önem arz etmektedir. Siyaset felsefesinin de temel noktalarından biri olan yönetme ve yönetilme konusu hem iletişimin hem de psikoloji ve sosyolojinin birlikte değerlendirilmesi gerektiğini ortaya koymaktadır. Uzun yıllardır bilimin konusu olan duygular, öznel oldukları kadar kolektif bir boyut da taşırlar. Çünkü küçük ya 
da büyük her tür grupta ortaya çıkan duygular, o gruptaki bireylerin çoğunluğu tarafından paylaşılır ve toplu olarak davranışa dönüştürülür (Gökçe, 2019, s. 1). Bu sebeple duyguların teklikten çokluğa doğru giden etkisi, seçmen duygularının yayılma sürecini birçok boyut ile düşünmeyi gerektirmektedir.

Dolayısıyla birey ve devlet arasındaki ilişki yaşamın vazgeçilmez en önemli unsuru olarak yöneten ve yönetilen ilişkisi durumunu ortaya koymaktadır. Aristo'ya göre yönetilenleri etkilemenin en önemli araçlarından birisi doğru bir iletişim stratejisi ile duygulara hitap edebilmektir. Özellikle politik söylevcilikte yönetenin; doğru algılanması, söylediklerinin inandırıcı olması ve dinleyicilerin onun hakkında olumlu bir düşünceye sahip olabilmesi için duygu faktörünü ön planda tutması gerekmektedir. Çünkü dinleyici sahip olduğu duygusal özellikler sebebi ile hem dostluk hem de düşmanlık ilişkisi için kolaylıkla karar verebilmektedir (Aristoteles, 1997, s. 97). Yine 16. yüzyılın en önemli düşünürlerinden biri olan Machiavelli de Prens adlı eserinde hükümdarın halkın duygularına nasıl seslenmesi gerektiğine dair önemli bilgileri şu şekilde sunmaktadır:

"...halkın lütfu sayesinde prens olan biri ise, halkın dostluğunu kazanmalıdır. Halkı ezmeyi istemediği için bunu sağlaması kolay olacaktır. Prensin halkın sevgisini kazanmak için pek çok yol vardır; ama bu yollar koşullara göre değişir. Bu yollara dair kesin kurallar konamaz. Bir prens halkılyla birlikte dostça yürümelidir" (Machiavelli, 2018, s. 44-45).

Hükümdar olan kişi yönetilenlerin rızasını almalı ve onların duygularının nasıl yönetileceğini iyi bir şekilde belirlemelidir. Bu anlamda "Halka dayanan batağa dayanır" sözü Machiavelli'nin karşı çıktığı bir durumdur. Çünkü iyi bir yönetici, halka dayanmış biridir ve otoritesini sağlamlaştırmak için yine halkın desteğini almalıdır. Bu da halkın var olan güce karşı razı gelmesi ile kalıc bir boyut kazanabilmektir (Machiavelli, 2018, s. 45). Machiavelli, yönetilenlerin çok değişken duygulara sahip olacağını ve kendi çıkarları söz konusu olduğunda var olan düşüncelerinin birdenbire değiş̧ebileceğini şu sözlerle ifade etmektedir:

"... Çünkü insanlar hakkında genelde şöyle söylenir: Onlar kararsız, yalancı, içten pazarlıklı, açgözlüdürler ve kendilerini çıkarlarına vermişlerdir. Eğer çıkarları varsa kendilerini sana adarlar. Önceden de söylediğim gibi gerekmedikçe kanlarını dökerler, mallarını, hayatlarını ve çocuklarını senin için kurban ederler; ama gerektiği zaman sana karşı dönerler. Tamamen onların sözlerine güvenen prens, başka önlemler almamışsa yıklır. Çünkü parayla elde edilmiş dostluklar ve asaletler; kazanılmış değildirler, gerektiğinde kullanılmazlar" (Machiavelli, 2018, s. 72).

Duyulara dokunan her uyarıcı, insanın duygularında ve karar mekanizmasında belli değişiklikler oluşturabilmektedir. Bu değişiklikler başııa ses, koku, tat, sıcaklık, acı, açlık, susuzluk ve genellikle dış 
uyarıcıların iç duyuları harekete geçirmesi ile gerçekleşmektedir (Descartes, 2013, s. 14-15). Halkın davranışlarındaki değişimlerin temel sebebi sosyalizasyon sürecindeki dış uyarıııların kuvvetli nüfuz etkisidir. Birey bu süreçte çeşitli duyguları olumlu ya da olumsuz olarak nitelendirerek siyasallaşma sürecinin bir parçası olmaktadır. Her bir nesne ve kişiyle kurulan duygusal temas, savunulan görüşe olumlu ya da olumsuz duygulanım yüklemektedir. Fakat bu duygular birbirinden bağımsız olmamakla beraber savunulan görüşün devam ettirilebilmesi adına büyük önem taşır. Aristoteles'in deyişi ile zevk ve acı, zengin lik ve yoksulluk, sevgi ve nefret gibi duygular birbirini birlikte var etmek için vardır ve aslında birbirlerinin devamı niteliğindedir (Aristoteles, 1997, s. 72). Dolayısıyla insana dair her duygunun kalıcı olmadığını ve çeşitli dışsal uyarıcılar sonucunda değişebileceğini söylemek mümkündür. Bunun tutum ile ilişkisini ortaya koyan bir çalışmada, insan davranışının süreklilik kazanmasında toplumsal değer, norm ve ilişkilerin önemine dikkat çekilmektedir. İnsan duyguları ve düşünceleri tutum bağlamında zor değişse dahi bu onun imkânsız olduğunu ifade etmemektedir. Dolayısıyla hem psikolojik hem sosyolojik bir süreç olarak tutum, yönetilen kitlenin duygularının değişebileceğine işaret etmektedir (İsen \& Batmaz, 2006, s. 278-280). Bu yüzden duygu kavramı, başından itibaren politik alanda kullanılabilecek en önemli insan parçasıdır. Çünkü etkileme ve etkilenme demek, dünyaya açık olmak, onun içinde etkin olmak ve karşııık vermesi için sabretmek anlamına gelmektedir (Massumi, 2018, s. 8-9).

\section{SIYASAL ILETIŞIMDE DUYGULARIN YERI VE ÖNEMI}

Siyasal iletişim; "Siyasal aktörlerin belli ideolojik amaçlarını, politikalarını belli gruplara, kitlelere, ülkelere ya da bloklara kabul ettirmek ve gerektiğinde eyleme dönüştürmek, uygulamaya koymak üzere çeşitli iletişim tür ve tekniklerini kullanmaları" olarak tanımlanabilir (Aziz, 2019, s. 3). Illetişim, toplumun dolayısıyla siyasetin merkezindedir. Siyasal bilginin üretilmesi ve yayılma sürecini kapsayan iletişim hem medya hem de kişisel etkileşimler sonucunda siyasal bilginin hedef kitleye ulaştııımasını sağlamaktadır (Cottam, Mastors, Preston, \& Beth, 2017, s. 267). Harold Laswell'e göre bir toplumdaki iletişimin üç temel özelliği vardır. Buna göre, iletişim bir toplumu etkileyecek olayların izlenmesini sağlar; toplumun üyeleri arasında bu bilginin bağdaştırımasına katkıda bulunmakta ve toplumun üyeleri arasında değer ve normların aktarılması işlevini görmektedir (Akt. Cottam, Mastors, Preston, \& Beth, 2017, s. 267).

Toplumsal olayların bir süreç niteliği taşıması ve dinamik bir yapıda olması, nüfus artışı, teknolojinin gelişmesi (Aziz, 2019, s. 4) gibi temel sebepler siyasal yapılanmaları da etkilemekte ve 
siyasilerin kullandığı iletişim türlerini de bu doğrultuda değişime uğratmaktadır (Oskay, 1982, s. 309310). Dinamik bir yapıya sahip olan toplum içerisindeki kitlenin düşüncelerini anlamak için, ardındaki motivasyona bakarak siyasal mesajlar kurgulanmalıdır. Bu noktada arzular, gereksinimler, hisler ve düşünceler (Oskay, 1982, s. 318) seçmen kararlarını etkilemede önemli bir rol oynamaktadır. Bir liderin kitleyi en kolay ve kalıcı bir şekilde etkilemesinin temel yolu, onlarla duygusal bağ kurmasıdır (Maxwell \& Dornan , 2002, s. 202-203).

Siyasal iletişim alanında insan beyni üzerine yapılan birçok araştırma, seçmenin hiç farkında olmadığı halde birçok uyarııının etkisi ile bilinçaltında karar verdiğini ortaya koymaktadır (Erdem \& Batı, 2016, s. 29). Yani seçmen davranışlarını yönlendiren sadece zihin değil aynı zamanda duygusal süreçlerdir. Bu doğrultuda her seçmenin karar verme ve tutum süreçlerinde farklı kapasite ve motivasyonların olduğunu belirtmek mümkündür. Tüm insanların temelde üç kapasitesi olduğunu belirten Batı, bu durumu "kuvve-i gadabiye, kuvve-i şeheviye ve kuvve-i akliye" olmak üzere üç şekilde sınıflandırmaktadır. Bunlardan kuvve-i akliye, zihni kapasiteyi ifade etmektedir. Sevinç, mutluluk, heyecan, üzüntü, kaygı, mizah ve sevgi ise kuvve-i gadabiye ve kuvvei şeheviye'ye karşlık gelmektedir. Bu bağlamda insanın fiziksel merkezli, zihinsel merkezli ve duygusal merkezli olmak üzere üç temel merkeze sahip olduğu söylenebilir (Batı, 2017, s. 211). Konumuz bağlamında da önem arz eden siyasal iletişimdeki duygu çalışmaları, siyasetin aşırı derecede duygu uyandıran bir alan olduğunu göstermektedir. Duygular, seçmenin zihnindeki tüm bölümleri etkilemekte ve aynı şekilde tüm bölümlerinden etkilenmektedir. Değerler, kimlikler, tutumlar duygusaldır ve duygusal bileşenlere sahiptir; ayrıca duygular seçmenin zihnindeki diğer bir yön olan biliş ile etkileşime geçmektedir (Cottam, Mastors, Preston, \& Beth, 2017, s. 37).

Dolayısıyla birey, edindiği bilgi karşısında duygusal faktörlerin de etkisi ile daha anlık tepkiler göstermekte (Güllüpunar, 2010, s. 12) ve davranışlarını gerçekleştirmektedir. Bu sebeple günümüzde birçok siyasi, seçmen kararlarını etkilemek amacıyla rasyonel boyutu arka plana atılmış, duygusal boyutu abartılmış ve sözel kanaldan çok görsel kanallara yaslanan bir siyasi söylem geliştirerek (Oskay, 2017, s. 38) duygusal faktörleri de siyasal kültürün içine katmaktadır. Duyguların siyasi yönü üzerine çalışan birçok isim, insanların siyasal konulara, aktörlere, olaylara ve aynı zamanda değer verdikleri siyasal ilkelere ve ideallere karşı duygusal tepkiler gösterdiğini de önemle vurgulamaktadır. Bireylerin bilgi 
işlemesinde duygunun önemine vurgu yapan Marcus, duygunun bu noktada ikili işlevine dikkat çekmektedir. Illk olarak duygu, bilindik ve tanıdık durumlara karşı bir yatkınlık oluşturmakta, ikincisinde ise bir gözetim rolü üstlenerek kişiyi yeni durumlara karşı uyarmaktadır (Akt. Cottam, Mastors, Preston, \& Beth, 2017, s. 104). Duygular, bilgi işlemeyi, karar almayı ve davranışları büyük ölçüde etkilemektedir. Olumlu duygular bireylerde sorun çözme, uzlaşma ve karar almayı hızlandırıcı bir etkiye sahipken, olumsuz duygular ise bireyin düşünce sistemini daha fazla aktifleştirerek çevreye yönelik yoğun bir dikkat ve tehdit algısını beraberinde getirmektedir (Cottam, Mastors, Preston, \& Beth, 2017, s. 105). Gabriel ve Westle göre ise, bireyde çevredeki bilinmedik ve tehlike arz eden durumları tarayan Behavioral Inhibition System yani gözetim sistemi olarak adlandırılan bir sistem bulunmaktadır. Bu sistem bireyin beklentileri ve gerçekliği arasında herhangi bir çelişki yaratılmıyorsa kişiyi güvende hissettirerek duygusal anlamda rahatlatmaktadır. Fakat tehdit veya beklenmedik durumlarla karşılaşıldığında ise korkuyu aktive ederek bireyin anlık rutinden kopmasına sebep olmaktadır (Gabriel \& Westle, 2012, s. 101). Gözetim sistemi, siyasal koşullara bağı olarak rahatlama ve sakinlik ya da kaygı ve huzursuzluk hislerini belirlemektedir. Her ikisi de insanları siyasal alana az ya da çok dikkat etmeye, adayların değerlendirilmesine ve siyasete katılmaya itmektedir (Cottam, Mastors, Preston, \& Beth, 2017, s. 109). Siyasal iletişimde hem olumlu hem de olumsuz duyguları harekete geçirecek birçok duygusal hareketlilik seçmene yönelik kurgulanmaktadır. Marcus ve arkadaşları farklı duygulanımların seçmen davranışında uyandırdı̆̆ı bu etkiyi iki farklı duygu üzerinden şu şekilde açıklamaktadır:

\begin{tabular}{|l|l|}
\hline $\begin{array}{l}\text { Bilindik ve ödüllendirici içeriğe yönelik duygu } \\
\text { uyarılması }\end{array}$ & $\begin{array}{l}\text { Bilinmedik ve belirsiz içeriklere yönelik duygu } \\
\text { uyarılması }\end{array}$ \\
\hline \multicolumn{1}{|c|}{ Coşku } & \multicolumn{1}{c|}{ Gerginlik } \\
\hline $\begin{array}{l}\text { Coşku gibi olumlu duyguların uyarılmasında } \\
\text { bireyin tanıdık ve bildik hisleri aktive } \\
\text { edilmekte ve kişinin düşünmeden daha önce } \\
\text { yaptığı oy verme davranışını gerçekleştirmesi } \\
\text { hedeflenmektedir. }\end{array}$ & $\begin{array}{l}\text { Gerginlik gibi olumsuz duyguların uyarılması } \\
\text { bireyin düşünce ve davranışlarını } \\
\text { sorgulatmakta ve seçmenin kendine yeni } \\
\text { alternatifler üretmesi hedeflenmektedir. }\end{array}$ \\
\hline
\end{tabular}

Şekil 1 Siyasi Alandaki Tepkiler (Marcus, Neuman, \& Keele, 2007, s. 128).

Seçmen davranışlarını belirlemede önemli bir yere sahip olan duygular aynı zamanda diğer gruplara dair algılarla şekillenmektedir. Tehdit edici olarak algılanan dış gruplar tehdit algısı arttıkça seçmenin duygusal düzeyini daha çok arttırmaktadır. Bunun yanında olumlu duyguları besleyen iç gruplar ise seçmenin motivasyonunu olumlu yönde arttırmakta ve savunulan ideoloji ile özdeşleşmeyi güçlendirmektedir (Cottam, Mastors, Preston, \& Beth, 2017, s. 106). Ancak bir iç grup üyesi olumsuz bir 
davranış sergilediğinde benzer davranış içerisinde bulunan dış grup üyesine göre daha olumsuz değerlendirilmekte ve buna yüz karası etkisi adı verilmektedir (Marques, Dominic , \& Paez, 2008, s. 401). Dolayısıyla genel olarak olumlu duyguların iç gruplarla, olumsuz duyguların ise dış gruplarla ilişkili olduğu söylenebilmektedir.

Amerikalı siyaset bilimci Kathleen Searles ve Travis Ridout ise, duygusal çekiciliğin siyasal iletişim kampanyalarında stratejik olarak kullanıldığına dikkat çekmektedir. Bu doğrultuda yapılan siyasi reklamların birçoğu seçmen duygularına yönelik kurgulanmakta ve en çok ilgi çeken duygu öğelerinin ise coşku, öfke ve korku olduğunu belirtmektedir (Akt. Scarantino, 2017, s. 3). Yine 1998'de Amerika başkanlık seçimleri sırasında yapılan korku ve coşku gibi duyguların seçmen davranışına yoğun etkide bulunduğu gözlemlenmiştir. Ortaya çıkan sonuçlara göre bu dönemde yapılan siyasal reklamların biçim ve içerik açısından coşku öğesini ön planda tuttukları ve bu durumun seçmen kararlarını doğrudan etkileyerek pozitif duygulanımın arttırılmasını sağladığı görülmüştür. Benzer şekilde korku öğesinin kullanımı ise dikkati arttırmakta ve seçmenin güncel değerlendirmelerini sorgulatmaktadır (Gabriel \& Westle, 2012, s. 104). Yapılan diğer bir araştırmaya göre ise seçmende öfke duygusunun harekete geçirilmesi siyasal katııımı güçlü bir şekilde motive edebilmekte normalde seçimlere katılmayacak kitleyi ya da tarafsız seçmen kitlesini dahi seçime sürüklemektedir (Valentino, Brader, Groenendyk, Gregorowicz, \& Hutchings, 2011, s. 168).

\section{DUYGULARIN SEÇMEN DAVRANIŞI ÜZERINDEKI ETKISINII TEMEL ALAN TEORILER}

Günümüzde seçim davranışları açısından incelendiğinde birçok teori, seçmen davranışlarını anlayabilmek için bilişsel süreçlerin yanında duygusal süreçlere de odaklanılması gerektiğini ifade etmektedir. Özellikle Amerika kökenli bu araştırmalar, kişilerin bilgileri nasıl topladığı, bu bilgileri nasıl işlediği, düşüncelerini nasıl oluşturduğu ve karara nasıl geçirdiği ile ilgilenen birçok teori ortaya koymaktadır (Gabriel \& Westle, 2012, s. 22). Seçmenlerin oy verme davranışını rasyonel karar verme anlayışı içerisinde açıklayan Anthony Downs, seçmenin partilere olan yaklaşımının, onların iktidara gelme kapasitesine bağlı olarak şekillendiğini savunmaktadır (Akt. Erdinç, 2012, s. 59). Siyasiler tarafından seçmen duygularının uyarılmasında kimi zaman rasyonel süreçler kullanılmakta kimi zaman ise duygunun bir parçası olan sezgisellik ile seçmenlerin bir tercihte bulunması sağlanmaktadır. Siyasilerin duygusal mesaj kodlamalarını başarılı kılabilmek için sezgisellik, kısayol davranışları teşvik etmesi 
seçmenin karar sürecini istenen yönde etkileyebilmektedir. Duygusal yüklemelerle oluşturulan bu mesajlar, duygusal tepkilerin siyasal iletişim ile doğrudan ilişkili olduğunu göstermektedir. Bu anlamda insan duygularının anlaşılabilmesi için belli modeller literatürde geliştirilmiş ve siyasal iletişim çalışmalarında da bu modellerin kullanımı yaygınlaştırılmıştır. Marcus, bu mesajların oluşumunda önemli rol oynayan duygusal faktörleri sınıflandırmak için duyguları üç ayrı model çerçevesinde toplamaktadır (Marcus, 1991, s. 102):

\section{Valens (Değer) Model}

İnanç ve tutum araştırmalarına yönelik olan bu yaklaşımda, duygular tutumun değerlendirici bir boyutu olarak (Valens), bir duygunun yönünü ifade etmektedir. Pozitif valense sahip duygular bir yöne yaklaşmamıza, negatif valense sahip olanlar ise uyarandan uzaklaşmamıza sebep olmaktadır. Valens kavramı karar mekanizması ile de oldukça ilişkilidir. Örneğin; bir araba satın almak, bir diş fırçası satın almaya oranla valensi daha fazla etkiler. Valens sayesinde bireyler gündelik hayatlarındaki birçok duyguya yükleme yaparak bunu harekete geçirmektedir (Morin \& Renvoise , 2019, s. 57). Marcus'a göre ise bireylerin inanç ve tutumları temelde duygusal, bilişsel ve davranışsal olmak üzere üç boyut içerisinde şekillenmektedir. Konunun çerçevesini oluşturan duygu boyutu, bireylerin pozitif, negatif ve nötr değerler ile yüklendiğini ve bu değerler doğrultusunda hareket ettiğini ifade etmektedir. Bu durum da duyguları tek kutuplu ya da çift kutuplu olarak ayırmak mümkündür (1991, s. 202-203). Tek kutuplu duygu değerinde (valens) memnuniyet ya da memnuniyetsizlik gibi bir duygu yansıması ortaya çıkmaktadır. Bu yargıya göre ıstırap çekmek memnuniyetsizlik kutbuna, coşkunluk ise memnuniyet kutbuna yakın bir duygudur. Çift kutuplu duygulara göre ise etkinleşme ve etkisizleşme durumu hakimdir. Buna göre telaşlı hissetmek etkinleşme boyutuna yakınken, uyuşukluk hissetme etkisizleşme boyutuna yakın bir duygu olarak örneklendirilebilir. Dolayısıyla duygular, değer ve uyarılmışlık düzeyine göre iki boyutta ele alınabilmektedir (Yilmaz \& Bekaroğlu, 2020, s. 2235).

Siyasal iletişim açısından değerlendirildiğinde; siyasiler tarafından oluşturulan her mesaj stratejisi belli bir duyguyu hedefleyerek kurgulanmakta ve seçmen duyguları istenilen duygu değeri ile bütünleştirilmeye çalışılmaktadır. Bu alanda yapılan bazı araştırmalara göre siyasiler tarafından 18 kelimeye negatif bir değer yüklenmekte ve seçmendeki 18 nötr duygusu değiştirilmeye çalışılmaktadır. Yine yapılan araştırma sonuçlarına göre siyasilerin nötr kavramlardan çok negatif yüklü değerler kullanmasının seçmeni daha fazla etkilediği öne sürülmektedir (Utych, 2018, s. 82-83). Buna göre 2016 
yılında yapılan Amerika Başkanlık seçimlerinde Trump'ın sıklıkla rakiplerini hedef alarak negatif duygu yüklü mesaj stratejileri kullandığı gözlemlenmiştir. Trump, rakiplerine yönelik "yalancı", "ezik" ve "çocuk gibi" ifadeler kullanarak seçmen duygularında rakip adaylara karşı olumsuz duygu uyarması yapmaktadır (Utych, 2018, s. 78). Bu şekilde yapılan siyasal iletişim çalışmaları ile seçmen duygularında kutuplaştırmalar oluşturulmakta ve belli bir duygu değerinin ağırlık kazanması istenmektedir.

\section{Ayrık Duygu Modeli}

Ayrık yaklaşıma göre kişinin geçmiş deneyimlerinden, öznel yaşantısından ve fizyolojik yapısından bağımsız olan bir duygu oluşumu söz konusudur (Kuppens, Ceulemans, Timmerman, \& Diener, 2006, s. 492). Ayrık modeli savunan kişiler, duyguların doğal seçilimle şekillenen, kendilerine özgü nöropsikolojik fenomenler olduğunu iddia etmektedir. Bu kişilere göre ayrık duygulara özgü bir nöral yapı vardır ve evrensel yüz ifadelerinin yanında hislerle de kendilerini var ederler (Akt. Aydın, Araz, \& Asan, 2011, s. 2). Bu modele göre her insanda yedi ile on arasında değişen belli duygu kavramları vardır ve bu duygular esasen binlerce duygunun karşılık geldiği temel kavramlardır. Ayrık duygu kuramına göre en iyi bilinen temel duygular mutluluk, sürpriz, üzüntü, öfke, kibir, iğrenme ve korkudur. Tomkins'e göre bu temel duygular herhangi bir kültürel farklılık olmadan tüm kişiler için benzer olarak belirlenmiş, ortak biyolojik tepkilerdir (Akt. Kılıç, 2020, s. 4-5).

Siyasal iletişimde ayrık duyguların başarılı bir şekilde kullanılması liderin yüksek düzeydeki politik bilgisine bağıdır. Bu anlamda liderin politik bilgisi arttıkça seçmenin duyguları üzerinde daha fazla politik retorik uygulayabileceği söylenebilir (Bakker, Schumacher, \& Roodijn, 2020, s. 3). Özellikle siyasal tutumların oluşturulmasında siyasilerin coşku ve korku gibi iki farklı duygu yoğunluğunu mesajlarında kullanmaları seçmenin odak noktasını etkileyebilmektedir (Utych, 2018, s. 81-82). Yine siyasal kampanya süreçlerinde sıklıkla kullanılan propaganda, halkla ilişkiler ve ikna çalışmaları, iletilerin doğrudan ve dolaylı olarak seçmene ulaşmasını gerçekleştirmektedir. Bu bağlamda siyasal iletişimin önemli bir parçası olan duygu faktörü siyasiler tarafından bütünleşik bir iletişim stratejisi ile kurgulanmayı gerektirmektedir. Aristoteles'in söylemlerinden de yola çıkarak bir siyasi liderin bilgisinin yanında seçmen davranışlarını etkilemek için hem kişisel duruş hem de akla ve duygulara hitap etmesi onu başarıya ulaştırabilmektedir.

Siyasal retoriğin bütünleşik bir şekilde kurgulanması ise; "üslup, sadelik, kendini analiz etme, hedef kitlenin özelliklerine uygun konuşma, geniş kelime haznesine sahip olma, yineleme, devamlılık, komplo teorisi, gerçeküstü senaryo üretimi, haklılaştırma, nedenselleştirme ve rıza üretimi gibi söylemler 
kitlelerin duygularını etkilemede önemli bir role sahiptir" (Zeybek, 2020, s. 195-196). Dolayısıyla siyasal bütünleşmeyi sağlayan en önemli araçlardan biri olan iletişim, siyasilerin seçmen ile duygusal bir bağ kurmalarında ve parti aidiyeti yaratarak bunun kalıcı bir zeminde ilerlemesinde önemli bir işleve sahip olmaktadır.

\section{Boyutsal Model}

Duyguların ölçülmesinde ve anlaşılmasında ortaya konan bir diğer model ise boyutsal modeldir. Bu modele göre duygular, hoşnutluk-hoşnutsuzluk ve uyarılma seviyesine bağlı olarak değişmektedir (Kılıç, 2020, 5. 3). Bazı araştırmacılara göre duygular az sayıda boyut etrafında şekillenmekte ve kategorilenebilmektedir. Bu araştırmadaki bazı görüşler duyguları olumlu ya da olumsuz olarak sınıflandııırken, bir diğer grup ise hoşnutluk/hoşnutsuzluk ve uyarılma/uyku şeklinde sınıflandırmaktadır. Yine bazı kuramcılara göre pozitif-negatif duygular birbirini etkilemezken, bazı kuramcılara göre ise birbirini etkileyen çift kutuplu tek boyuta sahip bir özelliği vardır (Akt. Aydın, Araz, \& Asan, 2011, s. 3).

Boyutsal modele göre duyguyu etkileyen faktörlerden ilki uyarılmışlık düzeyi, bir diğeri ise duygusal değerlik düzeyidir. Buna göre hoşluk veya nahoşluk, duygusal yüz ifadeleri uyarıcıların duygusal değerini tarif etmektedir. Olumlu değerliğe sahip duygular daha çok iştah durumunu ifade ederken, olumsuz değerlikteki duyguların ise daha çok savunmaya yönelik duygu hareketliliğini ortaya çıkardığı gözlemlenmektedir (Akt. Erdoğan, 2016, s. 9-10).

Siyasal iletişim çalışmalarında yapılan faktör analizlerine göre negatif duygular olarak bilinen öfke ve kaygı ortak bir boyuta yükleme yapmakta, siyasi muhakeme ve öğrenme üzerinde benzer etkilere sahip olduğu ortaya konulmaktadır. Yani bu duygular farklı gruplar olarak ele alınsa dahi negatif yönlü tek boyuta karşııık gelen ve aynı hisleri uyaran özelliklere sahiptir. Dolayısıyla çok sayıda duygusal uyarıcının olması bu alanda yapılan çalışmaların duyguları pozitif ve negatif şekilde ayırarak analiz edildiğini ortaya koymaktadır (Valentino, Brader, Groenendyk, Gregorowicz, \& Hutchings, 2011, s. 158-159).

\section{KARAR VERME SÜRECINDE SIYASAL REKLAMLAR}

Günümüzde kitle iletişim araçlarının etkisinin oldukça artması ve reklamın kendine birçok yeni mecra oluşturması, siyasal reklamların seçim iletişiminde önemli bir öğe olmasını sağlamaktadır. Reklamın birçok farklı mecrada var olması ve hedef kitleye hızlı bir şekilde ulaşması, seçim iletişiminde reklamın önemli bir alan olduğunu ortaya koymaktadır. Siyasal reklamın seçim iletişiminde tercih 
edilmesinin temel sebepleri arasında ise mesajlarda tekrar unsuruna sıklıkla yer verilmesi ve mesajın kitleler tarafından içselleştirmesini kolaylaştırması yer almaktadır (Cömert, 2019, s. 101-102).

Siyasal reklamlar akılda kolaylıkla kalan yapısı, basit görsel, işitsel ve dilsel anlatımı ile geçmişten bugüne seçmeni kısa sürede hem mantıksal hem de duygusal süreçlerle etkilemektedir. Oy sayısını arttırmak veya desteklemek, siyasi aday ya da partinin farkındalığını arttırmak, kimliğini geliştirmek, tutumlarına etki etmek ve eğitmek gibi siyasal amaçları içeren (Uztuğ, 2003, s. 8) siyasal reklamlar, belli bir fikir, strateji, tema, metin platformu ve metin stratejisi ile hedef kitleye sunulmaktadır. Bu doğrultuda oluşturulan mesaj stratejileri kurgulanırken temelde hedef kitleye akılcı ve duygusal imaj ikilikleri içinde seslenilmekte ve hedef kitlenin istenilen yöne çekilmesi hedeflenmektedir. Dolayısıyla duygu-zihin ayrımına karşılık gelen imaj reklamcılığı ise hedef kitle ile kurduğu ilişkide sözcükler, gerçekler ve iddialardan çok duygulara ya da güçlü imajlara yer vererek hedef kitleyi duygusal kodlamalarla ikna etmeye çalışmaktadır (Uztuğ, 2003, s. 9). Bu noktada imaj reklamlarının temelde lider imajı, lider + parti imajı ve parti imajı şeklinde kurgulandığını ifade etmek mümkündür (Uztuğ'dan akt.Balcı \& Bal , 2008, s. 9).

Pozitif ve negatif reklam olarak iki kategoride tasarlanan siyasi reklamlar, olumlu ve olumsuz duygu yaratmada oldukça etkilidir. Negatif reklam kampanyaları, bir adayın diğer bir adayın ismini vererek eleştirmesidir. Pozitif reklamda ise aday kendisini tanıtmaktadır. Fakat bu durum negatif reklamların yalnızca olumsuz duygularla kurgulandığı anlamına gelmemektedir. Aynı şekilde pozitif reklamlarda da kızgınlık veya korku gibi negatif duygular uyandırılabilmektedir (Cottam, Mastors, Preston, \& Beth, 2017, s. 282). Siyasal reklamcılıkta hikâye anlatımının önemine vurgu yapan Uztuğ, hikâyenin bir tür zihinsel uzam olduğunu ve hedef kitlenin bilinçaltına kolaylıkla erişebildiğini savunmaktadır. Kendine özgü bir güç ve konumlandırma oluşturan hikayeleştirme, duygusal içerik ve zenginleştirmelerle (2009, s. 124) seçim iletişiminde kitlenin algısını büyük ölçüde şekillendirmektedir.

Siyasal iletişimde temelde üç tür ikna edici mesaj stratejisi üzerinde durulmaktadır. Bunlar duygusal, rasyonel ve ahlaki çekiciliktir. Rasyonel çekicilikte hedef kitleyi ikna etmek için somut kanıtlar kullanılır ve bu rasyonel çekiciliğin temelini oluşturur. Bu sayede hem rakibin aleyhine veriler toplanıp sunulmakta hem de seçmenin hedeflenen yönde karar vermesi istenmektedir. Duygusal çekicilik hedef kitlede mutluluk, iyi niyet, korku, gurur, vatanseverlik, kızgınlık, hüzün, birlik, beraberlik, heyecan, coşku 
ve umut gibi özel his ve duyguları uyandırarak hedef kitlenin tutumlarında değişiklik oluşturmayı planlamaktadır. Son olarak ahlaki çekicilik ise adayın ahlaki değerlerini ön plana çıkararak (Akt. Balcı \& Bal , 2008, s. 16-17) seçmenin toplumsal norm ve kurallar çerçevesinde dürüst, güvenilir ve ahlaklı bir imaj oluşturmasını hedeflemektedir.

\section{AK PARTi VE CHP'NIN DUYGUSAL IÇERIKLI REKLAMLARI ÜZERINE BíR ANALIZ}

\section{Amaç ve Yöntem}

Çalışmanın literatürü bağlamında yoğun bir şekilde açıklanan duygu faktörü, AK Parti ve CHP'nin Yerel ve Genel Milletvekili Seçimleri ile Cumhurbaşkanlığı Seçimlerindeki reklamları üzerinden değerlendirilmeye alınacak ve duygusal analizler çalışma içerisinde ortaya çıkarılacaktır. Çalışma sürecinde belirtilen dönemlerdeki diğer Yerel ve Genel Milletvekili Seçimleri ile Cumhurbaşkanlığı Seçim reklamları incelenmiş, bu doğrultuda duygu öğesinin yoğun olarak kullanıldığı reklamlar değerlendirmeye alınmıştır. Bu sebeple seçilen reklamlarda belirli bir kategori ve tarih aralığı belirlenmemiştir. Yapılan literatür incelemesinde de benzer çalışmaların olduğu gözlemlenmektedir.

Araştırmanın evrenini siyasal iletişim alanındaki reklamlar oluştururken, örneklemini ise Ak Parti ve CHP'nin Yerel ve Genel Milletvekili Seçimleri ile Cumhurbaşkanlığı Seçim reklamları oluşturmaktadır. Nitel araştırma yöntemi içerisinde yer alan içerik analizi ve betimsel analiz tekniği, belirtilen reklam filmlerinin çözümlenmesinde yöntem olarak kullanılmıştır. Neuman, içerik analizi tekniğini, yazılı belge veya diğer iletişim araçlarında bulunan içerikleri, bilgileri veya sembolleri araştırmak için kullanılan bir teknik olarak ifade etmektedir (2014, s. 49). Nitel yöntem içerisinde ele alınan içerik analizi, yazılı ve görsel unsurların analizinde yaygın olarak kullanılan bir tekniktir. Bir içerik analizi yapmak için öncelikle belli bir kategori ya da kategoriler oluşturulur ve belli kelime, cümle veya görseller analiz edilerek çalışmanın amacına uygun olarak yorumlanır (Özdemir, 2010, s. 335). Nitel yöntem içerisinde kullanılan bir diğer teknik ise betimsel analiz tekniğidir. Betimsel analiz tekniğinde araştırmacı bireylerin görüşlerini açığa çıkarmak için doğrudan alıntılar kullanabilmektedir. Bu analiz biçiminde amaç elde edilen bulguların okuyucuya özetlenmiş ve yorumlanmış bir şekilde aktarılmasını sağlamaktır (Özdemir, 2010, s. 336). Bu teknikte "tanıtıı bulgular değerlendirilir, içerik analizi yoluyla veriler tanımlanmaya çalışılır birbiri ile ilişkili olduğu tespit edilen kavramlar ve temalar bir araya getirilerek yorumlanır" (Karataş, 2015, s. 70). Buradan hareketle belirlenen siyasal reklamlarda nitel araştırma yöntemi içerisinde yer alan betimsel 
analiz ve içerik analizi yöntemi kullanılacak ve duygusal mesajlar tablolaştırılarak analiz edilecektir. Araştırma içerisinde ele alınan reklam filmlerine youtube kanalından ulaşıımış olup saniye saniye izlenerek belirlenen tekniklere uygun olarak analiz edilmiştir. Bu doğrultuda siyasal reklamlarda öne çıkan konular, kullanılan ikna edici duygusal unsurlar, yayınlandığı mecralar konu içerisinde açımlanmaya çalışılmıştır. Siyasi reklamlarda üstü örtülmüş anlam yapılarını ortaya çıkarmak, reklamlarda açıkça vurgulanmayan ve direk olarak ifade edilmeyen yapıların çözümlenmesi için nitel olan içerik analizi yöntemi bu noktada tercih edilmektedir.

Çalışma temelde seçmen davranışlarının duygusal faktörlerden de yoğun olarak etkilediğini ortaya çıkarmayı amaçlamaktadır. Bu amaç doğrultusunda çalışmada şu sorulara yanıt aranmaktadır:

1. Seçmen davranışları yalnızca rasyonel karar verme süreçleri doğrultusunda mı gerçekleşmektedir?

2. Siyasi partiler, seçmen tercihlerini belirlemede duygusal öğeler kullanmakta mıdır?

3. Seçmen kararlarını etkilemek için siyasiler, hangi kategorilerde duygu yüklemesi yapmaktadır?

Yapılan literatür çalışmasına göre siyasi partilerin seçmen kararlarını etkilemede sıklıkla duygusal öğelere yer vermesi, seçmenin davranışlarını etkilemede oldukça güçlü bir bilinç altı etkisi yaratmaktadır. Duygular siyasi alanda yoğun olarak kullanılan ve ikili işleve sahip önemli bir taşıyıcıdır. Bu ikili işlevi temelde olumlu ve olumsuz duygu kategorisi şeklinde yorumlayan Marcus ve arkadaşları, olumlu ve bilindik duyguların bireyin karar verme sürecini hızlandırdığını ve daha uzlaşmacı bir yapıya bürünebildiğini ortaya koyarken, olumsuz ve bilinmedik duygularda ise bireyin daha fazla risk ve tehdit algısı hissettiği, bu sebeple daha fazla kaygı ve huzursuzluk durumu yaşadığını ortaya koymaktadır (2007). Siyasal iletişimde hem olumlu hem de olumsuz duyguları harekete geçirecek birçok duygusal hareketlilik seçmene yönelik kurgulanmaktadır. Buradan haraketle çalışmanın araştırma kısmında belirlenen siyasi partilerin duygusal mesaj kodlamaları olumlu ve olumsuz duygu kategorileri bağlamında ele alınacaktır. 


\section{Bulgular}

\section{Zümrüdü Anka Türkiye Vakti AK Parti}

Siyasal reklamcılığın örneklerinden birisi olan ve AK Partinin 2018 genel ve Cumhurbaşkanlığı seçimlerinde yayınlamış olduğu "Zümrüdü Anka Türkiye Vakti AK Parti" reklamı, seçimlere kısa bir süre kala televizyon ve internet ortamından seçmen kitlesi ile buluşmuştur. Zümrüdüanka reklam filminde kullanılan müzik Plevne Marşı'ndan oluşurken, reklam filmi süresince "AK Parti Genel Başkanı ve Cumhurbaşkanı sıfatlarını taşıyan Recep Tayyip Erdoğan şiir okumaktadır" (Aksoy, 2019). Mitoloji ve hikayeleştirme unsuruna yoğun bir şekilde yer veren reklam filmi, güneşin doğuşu ile başlamakta ve Zümrüdüanka kuşu doğan yeni güneşin önünden geçmektedir. Tarihsel geçmişe önemle atıfta bulunan reklam filminde küllerinden doğan Zümrüdüanka kuşu reklam boyunca önemli isimlerin üzerinden geçmektedir. Recep Tayyip Erdoğan; "Alparslan, Fatih Sultan Mehmet, Kanuni Sultan Süleyman ve Mustafa Kemal Atatürk" gibi lider kişiliklerin ismini sayarak şiiri seslendirmektedir. İslam mitolojisinde kuşların şahı olarak bilinen Zümrüdüanka kuşu, İran mitolojisinde ise 30 kuştan meydana gelmiş ve onların özelliklerini taşıyan değerli bir kuştur (Barış, 2018, s. 57). Belirlenen reklam filminde ise Türk milletinin önemli bir sembolü olan Zümrüdüanka kuşu, Türklerin geçmişten bugüne köklü bir geçmişe sahip olduğu ve milletin benliğini bulması, unutmaması şeklinde görselleştirilmişstir. Reklam filminde Osmanlı'dan Cumhuriyet'e ve oradan AK Parti dönemine kadar hareket eden Zümrüdüanka kuşu, AK Parti döneminde yapılan otoyollar, üçüncü köprü, barajlar, tüneller, şehir hastaneleri gibi yapıların üzerinden uçarak AK Parti döneminde yapılan yenilikleri göstermekte ve AK Parti dönemi ile Türkiye'nin küllerinden yeniden doğduğu ve şahlandığına atıfta bulunmaktadır (Aksoy, 2019). Başlasın en güçlü devir söylemi ile Recep Tayyip Erdoğan, "yenilenmek, şahlanmak, dört nala koşmak için, kavgayı, kederi, kaderimiz bu söylemini geride bırakarak, birlik, bereket, bolluk için Türkiye dönemi Türkiye vakti" diyerek reklam filmini sonlandırmaktadır. Reklam içerisinde duygusal öğelerin yoğun bir şekilde kullanıldı̆̆ı görülmekte ve bu şekilde seçmen kitlesinin hem bilincine hem de bilinç altına seslenilmektedir. Reklamın en etkili unsurlarını içerisinde barındıran Zümrüdü Anka Türkiye Vakti AK Parti reklamı, liderin duygu dolu seslendirmesi, hitabet sanatını kullanışı, ses tonu, müziğin şiirle birlikte oluşturduğu duygusal etki, tarihsel öğelere vurgu yapması, ortak bir bilinç üzerinden kitlesel söylem üretmesi, benlik olgusundan bizlik durumuna geçilmesi gibi noktalarla seçmen kitlesinin zihninde duygusal bir bellek oluşturmaktadır. 
Insanda olumlu duyguları canlandıran bu reklam filmi izleyicilerde, gurur, mutluluk, heyecan, umut ve vatanseverlik duygularını uyarmakta ve seçmeni harekete hazırlamaktadır. Uyarılan bu hisler ise seçmenin eyleme doğru geçme sürecinin önemli bir parçasını oluşturmaktadır.

\begin{tabular}{|c|c|}
\hline Başlık: & Zümrüdü Anka Türkiye Vakti AK Parti \\
\hline URL: & https://www.youtube.com/watch?v=SOSbyFtAbo8 \\
\hline Olumlu Duygu Kullanımı & $\begin{array}{l}\text { 1- Uyuyan Osman Gazi'nin göğsünden altın renkli ve yapraklı bir çınar ağacı } \\
\text { yükselmektedir. Anadolu kültüründe düzeni, otoriteyi, kalkınmayı ve gelişmeyi } \\
\text { sembolize eden çınar ağacı, oldukça uzun yaşayan bir ağaçtır bu da Türklerin geçmiş } \\
\text { ile bugün arasındaki köklü geçmişine atıfta bulunarak vatan, yurt, millet sevgisi gibi } \\
\text { duyguları ortaya çıkarmaktadır (Okmeydan, 2018, s. 4330). }\end{array}$ \\
\hline Olumlu Duygu Kullanımı & $\begin{array}{l}\text { 2- İstanbul'da kılııını göğe kaldırıp atını şahlandıran Fatih Sultan Mehmet ise devleti } \\
\text { sembolize etmektedir. Bu karede söylenen "senin kudretinin ulaştığı yere onların } \\
\text { hayalleri dahi ulaşamasın" sözü kitlede coşku, heyecan, yücelik, cesaret gibi duyguları } \\
\text { aktive ederek düşmana karşı üstünlük duygularını ortaya çıkarmaktadır. }\end{array}$ \\
\hline Olumlu Duygu Kullanımı & $\begin{array}{l}\text { 3- Çölden geçerken atından inen kişi ise Yavuz Sultan Selimi temsil etmektedir. } \\
\text { Rivayete göre Osmanlı ordusu Mısır fethinde, Sina çölünü geçmek durumunda kalmış } \\
\text { ve bu zorlu yolculuğun ortasında birden atından inip önüne bakarak yürüyen Yavuz } \\
\text { Sultan Selim'in bu hareketi vezirler ile askerler arasında merak uyandırmıştır. Padişah, } \\
\text { bu hareketin anlamını ve nedenini kendisine soran vezirlere ve askerlere dönerek şu } \\
\text { yanıtı vermiştir: Iki cihan sultanı Peygamber Efendimiz önümüzde yaya yürürken biz } \\
\text { nasıl at üstünde olabiliriz? (Akt. Okmeydan, 2018, s. 50). Bu şekilde seçmenlerin } \\
\text { zihninde dini söylemlerin etkisi ile saygı, sevgi, geçmişe tutku, ölçülü olma, nezaket } \\
\text { gibi duygular uyandırılmaktadır. }\end{array}$ \\
\hline Olumlu Duygu Kullanımı & $\begin{array}{l}\text { 4- Zifiri karanlıkta denizde duran Bandırma vapurunda ise Mustafa Kemal Atatürk, } \\
\text { cumhuriyetin yeniden kurulması ile yeniden doğuşu temsil etmektedir. Mustafa } \\
\text { Kemal Atatürk'ün de bu reklamda kullanılması, AK Partinin hedef kitlesini geniş̧ } \\
\text { tuttuğunu göstermekte ve hedeflenen her iki kitlede de sevinç, coşku, vatanseverlik } \\
\text { gibi olumlu duygular uyarılmaktadır. }\end{array}$ \\
\hline Olumlu Duygu Kullanımı & $\begin{array}{l}\text { 5-Zümrüdüanka kuşunun son sahnede Recep Tayyip Erdoğan'ın başının üstünden } \\
\text { geçmesi ise kendisinin geçmişten gelen kişiler gibi Türk milletinin geleceği için çalıştı̆̆ } \\
\text { ve yapmış olduğu otoyollar, köprüler, barajlar, tüneller ve hastaneler ile Türkiye'yi } \\
\text { önemli ölçüde geliştirdiği belirtilmektedir. Bu sayede hikayeleştirme unsurunun son } \\
\text { noktası olan bu sahne, en güçlü devrin bu dönem olduğunu ifade ederek kişilerin } \\
\text { devlete bağ|lığı, saygısı, sevgisi, gururu, coşkusu, heyecanı, mutluluğu ortaya } \\
\text { çıkarılmaktadır. }\end{array}$ \\
\hline
\end{tabular}




\section{Millet Eğilmez Türkiye Yenilmez}

AK Parti'nin "Millet Eğilmez Türkiye Yenilmez" reklamı 12 Mart 2014 tarihinde roadblock yöntemi ile televizyonlarda yayınlanmaya başlamıştır (Doğan \& Aslantaş, 2015, s. 41). Üç dakikalık olan bu reklam filminde millet kavramı özellikle ön planda tutulmuştur. Bu anlamda "Millet Eğilmez Türkiye Yenilmez" sloganı ile yayınlanan bu reklam filmi doğrudan milli duyguları hedef alan mesajlar içermektedir. Reklam filminde hem köy hem de kentten karelerin sunulması tek bir millet olmaya çağrının en önemli göstergesidir. Bu anlamda "esnaf, çiftçi, iş adamı, yaşlı, genç, çocuk, erkek, kadın, başı açık, başörtülü, kentlisi, köylüsü" olmak üzere toplumun her kesiminin (Doğan, 2015, s. 262) tek vücut olması gerektiği aktarılmaktadır. Bunu yaparken de herkesin karşısında duran ve milletin, vatanın birliğini ve bütünlüğünü bozmaya çalışan bir düşman öğesi oluşturularak korku çekiciliği kullanılmaktadır.

Recep Tayyip Erdoğan bu reklam filminde dış ses olarak yer almakta ve İstiklal Marşı'nın beşinci ve onuncu kıtalarını okumaktadır (Göksu, 2019, s. 613). Bu reklam filminde göğe çekilmiş Türk Bayrağı gizli güçler tarafından aşağı indirilmekte ve halk toplu bir şekilde tepki göstererek yere indirilmeye çalışan bayrağı göğe çıkarmaya çalışmaktadır. Vatan, bayrak, millet gibi duygusal formların yoğun olarak kullanıldığı bu reklam filminde, korku çekiciliği de oldukça aktif işlenmiş̧tir. Kurtuluş savaşında milletin yoğun bir çaba gösterdiği mücadele, milletin zaferi ile sonuçlanmış ve İstiklal Marşı bunun bir simgesi olarak yazıımıştır. Yine bu reklam filminde de bayrağı göğe çıkarma mücadelesi millet tarafından gerçekleştirilmekte ve arka fonda İstiklal Marşı okunmaktadır. Bu sayede vatan ve millet arasındaki bağ yeniden zihinlerde canlandırılmakta ve vatanseverlik, cesaret, umut, gurur, coşku gibi temel insani duygular ortaya çıkarılmaktadır. Fakat düşman algısının da oluşturulduğu bu reklam filminde, korku, kızgınlık, öfke, üzüntü gibi olumsuz duygularda mesaj stratejisi içerisinde oluşturulmuştur. Yine reklam filminde Recep Tayyip Erdoğan tarafından İstiklal Marşının beşinci ve onuncu kıtalarının okunması milletin birlik ve bütünlüğüne çağrı yapıldığını ve Türkiye'nin hiçbir zaman özgürlüğünden ödün vermeyeceğine işaret etmektedir (Göksu, 2019, s. 613). Bu anlamda birçok farklı duygu teması eşliğinde birlik olan kişiler, reklam boyunca bayrağı göğe yeniden çıkarmak için yoğun bir mücadele vermiş ve "hakkıdır hür yaşamış bayrağımın hürriyet, hakkıdır hakka tapan milletimin istiklal" sözleri ile reklam filmi sonlandırılmıştır. Yapılan bu reklam filmi sadece pozitif reklamcılık unsurlarını değil, negatif unsurların da yoğun olarak kullanıldığını göstermektedir. 


\begin{tabular}{|c|c|}
\hline Başlık: & Millet Eğilmez Türkiye Yenilmez \\
\hline URL: & https://www.youtube.com/watch?v=80J0FCe69to \\
\hline $\begin{array}{l}\text { Olumsuz Duygu } \\
\text { Kullanımı }\end{array}$ & $\begin{array}{l}\text { 1- Gri ve puslu bir havada siyah takım elbiseli birinin gizlice bayrak direğinin içerisinde } \\
\text { bulunan mekanizmadaki ipi bayrağı indirecek şekilde çevirmesi korku duygusunun } \\
\text { hedef kitlede uyanmasına sebep olmaktadır. İnen bayrağın herkesin üzerinden bir } \\
\text { karartı oluşturarak geçmesi hüzün, keder gibi duygu oluşumlarını devamında } \\
\text { getirmektedir. }\end{array}$ \\
\hline $\begin{array}{l}\text { Olumsuz Duygu } \\
\text { Kullanımı }\end{array}$ & $\begin{array}{l}\text { 2- "Arkadaş! Yurdumu alçakları uğratma, sakın." cümlesi ile başlayan reklam filmi } \\
\text { vatana ve bayrağa yönelik bir saldırıya işaret ederken "Siper et gövdeni, dursun bu } \\
\text { hayasızca akın." dizeleri ile de milletin bu tehdidi algıladığı görülmektedir. Olumsuz bir } \\
\text { duygu oluşumunu ortaya çıkaran bu cümle, ilerleyen dakikalarda milletin gücü ile } \\
\text { olumlu duyguların oluşumunu beraberinde getirmektedir. }\end{array}$ \\
\hline $\begin{array}{l}\text { Olumlu Duygu } \\
\text { Kullanımı }\end{array}$ & $\begin{array}{l}\text { 3- Birlik duygusunu oluşturmada önemli bir parça olan İstiklal Marşı ve İstiklal } \\
\text { Marşının bir parçası olan "bu ezanlar ki şehadetler dinin temeli" söylemi dini ve vatan } \\
\text { duygularının birleşmesini sağlayarak köyden kente her kesimin bütünleşmesi } \\
\text { gerektiği belirtilmektedir. Arka fonda bir yandan Recep Tayyip Erdoğan tarafından } \\
\text { İstiklal Marşının söylenmesi bir yandan da ezanın okunmaya başlanması bu duyguların } \\
\text { herkeste birleştirici ve bütünleştirici bir rol oynamasını sağlamaktadır. Ortak kodların } \\
\text { kullanımı bu anlamda duygu akışını etkileyebilmekte ve kitlesel algıyı } \\
\text { şekillendirebilmektedir. }\end{array}$ \\
\hline $\begin{array}{l}\text { Olumlu Duygu } \\
\text { Kullanımı }\end{array}$ & $\begin{array}{l}\text { 4- Reklamda ezan, cami ve namaz kılan kişinin gösterilmesi ise dini duyguların gücünü } \\
\text { ve bütünleştirici özelliğini desteklemektedir. Bu da olumlu duyguları harekete geçiren } \\
\text { önemli bir unsurdur. }\end{array}$ \\
\hline $\begin{array}{l}\text { Olumlu Duygu } \\
\text { Kullanımı }\end{array}$ & $\begin{array}{l}\text { 5- Bayrağın millet tarafından yeniden göğe yükseltilmesiyle coşku, gurur, mutluluk, } \\
\text { övünç gibi duyguların oluşması sağlanmıştır. }\end{array}$ \\
\hline
\end{tabular}

\section{Milletçe Alkışlıyoruz}

7 Haziran 2015 genel başkanlık seçimlerinde iki aşamalı bir iletişim stratejisi planlayan CHP, ilk aşamada milletçe alkışlıyoruz temalı, iktidarı protesto eden bir reklam filmi hazırlamıştır. İkinci aşamada ise Türkiye'nin temel sorunlarına dikkat çeken ve bu sorunlara bir çözüm niteliğinde bir iktidar olarak kendisini sunmaktadır (Özkan, 2016, s. 18). Milletçe Alkışııoruz sloganı ile CHP hem internet hem de televizyon üzerinden bir dakikalık bir reklam filmi yayınlamıştır. Bu reklam filminde CHP negatif reklam kategorisinde mesaj stratejisi kurgulayarak Türkiye'nin kronikleşmiş sorunlarını ön plana çıkarmış ve iktidarın yarattığı bu sorunlardan en çok etkilenen kitleye reklam filminde yer verilmiştir. Milletçe Alkışlıyoruz reklam filminde ağırlıklı olarak duygusal öğelere yer verilirken aynı zamanda ekonomi, sağlık gibi konularda seçmenin rasyonel boyutuna hitap etmek üzere kurgulanmıştır. Ayrıca reklamda kullanılan 
dış ses, bir erkek sesi olarak belirlenirken, halkın sesleri de arka planda verilmiştir. Hem duygusal hem de rasyonel hikâye anlatımına ağırlık verilen bu reklam filminde davul ritimleri (Özkan, 2016, s. 18) ağırlıklı olarak kullanılmış ve alkış sesleri ile iktidar protesto edilmiştir. Ülkenin sıkıntılı durumlarına değinen CHP, reklam filminde "malum zihniyetler" söylemi ile iktidarı işaret ederek iktidara karşı (Göksu \& Özkoyuncu, 2015, s. 120-121) seçmende olumsuz duygular uyarmaya çalışmaktadır. Reklamda yer verilen doktor, kadın işçiler, balıkçılar, maden işçileri, esnaf, taksi durağındaki taksiciler, kuaförler, kahvede oturan kişiler ve tarım işçileri hep birlikte alkışlayarak iktidarı protesto etmekte ve tek negatif duygu örüntüsü etrafında buluşmaktadır. Hep bir ağızdan "Alkışlıyoruz, milletçe alkışlıyoruz" sloganı ile iktidara karşı̈ öfke, kızgınlık, çaresizlik ve üzüntü ifadeleri belirten kitle, jest ve mimik yapıları ile de olumsuz duygu yüklemelerini ifade etmektedir. Negatif siyasal reklam kategorisine giren bu reklam "doğrudan saldırı reklamı" olarak nitelendirilebilir. Dış ses: "Bu alkış hakka, hukuka ve ekonomiye, özgürlüğe, barışa ve adalete, laikliğe, demokrasiye ve cumhuriyete zulmeden malum zihniyeti protesto alkışıdır." cümlesi ile tüm okları iktidara yöneltmektedir (Vodinalı \& Çötok, 2015, s. 571). Bunun yanında reklamda kullanılan olumsuz duyguların seçmendeki gözetim sistemini aktive ederek içinde bulunulan yoğun tehlike durumuna karşı dikkat çektiği ifade edilebilir.

\begin{tabular}{|c|c|}
\hline Başlık: & Milletçe Alkışlıyoruz \\
\hline URL: & https://www.youtube.com/watch?v=F18g9AQheck \\
\hline $\begin{array}{l}\text { Olumsuz Duygu } \\
\text { Kullanımı }\end{array}$ & $\begin{array}{l}\text { 1- Reklam filminde birçok farklı meslek grubundan kişinin bir araya gelerek } \\
\text { alkışlamaya başlaması iktidara yapılan bir eleştiri niteliği taşımaktadır. Protesto amacı } \\
\text { ile yapılan bu eylem, iktidara karşı duyulan öfke ve kızgınlık duygularını uyarmaktadır. } \\
\text { Yine reklamdaki insanların yüz ifadeleri negatif duygu durumunun teşvik edildiğini } \\
\text { desteklemektedir. }\end{array}$ \\
\hline $\begin{array}{l}\text { Olumsuz Duygu } \\
\text { Kullanımı }\end{array}$ & $\begin{array}{l}\text { 2- Olumsuz mesaj stratejilerinin kurgulanması seçmenin konuya daha fazla dikkat } \\
\text { çekmesini sağlamaktadır. Bu sebeple "Milletçe Alkışı̆ıyoruz" reklam filminde "Bu alkış } \\
\text { hakka, hukuka ve ekonomiye, özgürlüğe, barışa ve adalete, laikliğe, demokrasiye ve } \\
\text { cumhuriyete zulmeden malum zihniyeti protesto alkışıdır. Türkiye'yi yaşanamaz bir } \\
\text { ülke haline getirenlere meydan okumadır. Alkışlıyoruz. Avuçlarımız patlarcasına } \\
\text { alkışlıyoruz. Milletçe. Alkışlıyoruz. Milletçe alkışıyoruz. Yaşanacak bir Türkiye geliyor." } \\
\text { söylemi ile CHP, negatif reklamcılık stratejisi ile seçmende farkındalık oluşturmaya } \\
\text { çalışmaktadır. }\end{array}$ \\
\hline
\end{tabular}




\section{Gelin Oy Verin Gitsinler!}

7 Haziran 2015 genel başkanlık seçimlerinin ikinci aşamasını oluşturan "Gelin Oy Verin Gitsinler!" reklam filmi ile CHP hem negatif hem de pozitif duyguları harekete geçirecek bir iletişim stratejisi uygulamıştır. Belirtilen reklam filminde ülkede var olan ekonomik kriz ön plana çıkarılarak halkın artık bu duruma tepki gösterdiği ve yeni bir alternatif olarak da CHP'ye oy verebileceklerini ifade eden bir mesaj kurgulaması yapılmıştır. İçinde bulunulan ekonomik bunalım, işsizlik ve yoksulluk gibi söylemler iktidara karşı olumsuz duyguların uyarılmasına sebep olurken, bu durumdan çıkılmasında kilit rol oynayacağı düşünülen CHP ise umut, sevinç, mutluluk, rahatlık, güven gibi olumlu duyguları harekete geçirecek bir özne konumundadır. Hem başı açık hem de başı kapalı her kesimden insana reklamda yer veren CHP, reklamda aksi görüşte olan kesim için dahi bir umut niteliği taşımaktadır. Özellikle ülkedeki olumsuz durumları halkın gözünden aktaran bu reklam filmi ile daha fazla farkındalık oluşturulmakta ve seçmenin farklı bir alternatif arayışına girmesi hedeflenmektedir. Bu durumla ilgili duygusal içerikli söylemler aşağıdaki tabloda sunulmaktadır.

\begin{tabular}{|l|l|}
\hline Başlık: & Gelin Oy Verin Gitsinler! \\
\hline URL: & https://www.youtube.com/watch?v=uVdMiJEUI5k \\
\hline $\begin{array}{l}\text { Olumlu Duygu } \\
\text { Kullanımı }\end{array}$ & $\begin{array}{l}\text { 1- Reklam filminde, "Ayağa kalkmış kararlı bir CHP görüyorum", "Bu defa iktidarı çok } \\
\text { isteyen bir CHP var" söylemleri CHP'ye kaşı olumlu bir bakış açısı olduğunu } \\
\text { yansıtmakta ve ülkeyi zor durumdan kurtaracak, ümit veren bir tablo çizmektedir. }\end{array}$ \\
\hline $\begin{array}{l}\text { Hem Olumlu Hem } \\
\text { Olumsuz Duygu } \\
\text { Kullanımı }\end{array}$ & $\begin{array}{l}\text { 2- "Millet işsiz, yoksul, aileler perişan, ekonomi gümlemiş CHP'ye oy verebilirim ben" } \\
\text { söylemi farklı kesimler tarafından tekrarlanmakta ve reklam filminde olumsuz } \\
\text { duygular harekete geçirilerek seçmende daha fazla farkındalık oluşturulmaya } \\
\text { çalışılmaktadır. Bu farkındalık sonucunda ise olumlu duyguları ortaya çıkaran CHP, } \\
\text { seçmende bir umut niteliği taşımaktadır. }\end{array}$ \\
\hline $\begin{array}{l}\text { Olumsuz Duygu } \\
\text { Kullanımı }\end{array}$ & $\begin{array}{l}\text { 3- Anket sonuçları tarafından seçmenlerin manipüle edildiği yine belirtilen reklam } \\
\text { filminde yer almakta ve halkın kandırıldığına dikkat çekilmektedir. "... Bir de anket } \\
\text { kandırmacası var. Yalan, seni ümitsizliğe kaptırmak için pompalıyorlar bu yalanları..." } \\
\text { söylemi anket sonuçlarına karşı halkın uyanık olması gerektiğini vurgulamaktadır. Bir } \\
\text { ikna unsuru olarak kullanılan bu veriler hem duygusal hem de mantıksal açıdan } \\
\text { seçmeni uyarırken aynı zamanda onları tekrar ikna etmeye dayalı bir ikna } \\
\text { mekanizması başlatmaktadır. }\end{array}$ \\
\hline
\end{tabular}




\section{Bulguların Değerlendirmesi}

Bulgular değerlendirildiğinde seçmenlerin duygusal yoğunlukta olumlu ve olumsuz mesaj içerikli siyasal reklamlarla karşı karşıya kaldığı ve bu durumun karar verme süreçlerini etkilediği ifade edilebilmektedir. Hem Ak Parti hem de CHP, seçmenlere yönelik duyguların ortaya çıktığı seçim çalışmalarıyla hedef seçmenleri etkilemeyi amaç edinmektedir.

Siyaset literatürü insanların oy vermeye giderken birçok rasyonel karar alma davranışının arkasında duygusal faktörlerin olduğunu göstermektedir. Seçmenlerin özellikle güvenlik, saygınlık, duygusal bağ|ılık, dini ve siyasal inanç, aidiyet (Erdem \& Batı, 2016, s. 211) isteği oy verme noktasında çok fazla uyarıcıdan etkilenmeye açık olduğunu ifade etmektedir. Seçmenin sahip olduğu hem sosyal hem de öznel kodlamalar siyasal davranışını da doğrudan etkilemektedir. Bireyin öğrenme ve sosyalizasyon yolu ile toplumsal çevreye ve rasyonel düşünceye bağlanmış olması, duygusal süreçlerden de bağımsız olmadığını desteklemektedir. Bu sebeple liderlerin özellikle seçmen gruplarını etkilemede duygusal ikna stratejilerini kullandığı açıça görülmektedir. Seçmen için hazırlanan iletişim stratejileri duygusal ikna mekanizmasının temelini oluşturmakta ve Laswell'in de meşhur siyasal insan formülünde belirttiği gibi seçmenlerde bu duyguları kamu yararı için rasyonalize etmektedir (Baykal, 1970, s. 96). Duygu, bu çalışmada siyasal iletişim üzerinden değerlendirilmiştir. Siyasal iletişimin duygusal boyutu üzerinden değerlendirilen dört reklam filminde hem olumlu hem de olumsuz kodlamaların yoğun olarak kullanıldığı görülmüştür. Yapılan analizler sonucunda risk algısını ortaya çıkaran negatif reklamcılık örneklerinin gözetim sisteminde de belirtildiği gibi seçmeni düşünmeye ittiği ve verdiği kararı tekrar tekrar sorgulattığı görülmektedir. Fakat risk ve tehdit algısını ortaya açıkça koyan negatif reklamların seçmen davranışlarını değiştirmede her zaman başarılı olduğu söylenememektedir. Riskin rasyonalize edilememesindeki temel sebep ise iktidar partisinin risklere dair tutumunun net olmasıdır. Bugüne kadar riskli olacak pek çok karara imza atmalarına rağmen, Recep Tayyip Erdoğan'ın sürekli söylemekten vazgeçmediği "Biz bu yola kefenimizle çıktık" söylemi, oy verme tercihleri açısından düşünüldüğünde duygusal olarak çok daha güçlü bir ifadedir (Erdem \& Batı, 2016, s. 109). Risk algısının bireyde uyarılması kimi zaman belirsizliğin de artması ile bireylerin rasyonellikten uzak bir karar vermesine sebep olabilmektedir. Bu durum seçmen kitlesinin kimi zaman olumsuz olarak algılanan bir durumu nötr ya da pozitif valens yükleme yaparak değiştirmesine sebep olmaktadır. Özellikle yüzer gezer seçmende sürekli 
öfke ve korku gibi duyguların uyarılması bireyin sinir sistemindeki endokrin bezini uyarmakta ve vücut adrenalinin salgılanmasına sebep olmaktadır. Öfkelenen insanın vücudundaki kan farkı bir organa aktarıldığı için beyin yeteri kadar rutininde işleyememekte ve rasyonel bir karar alamamaktadır (Batı, 2017, s. 185). Dolayısıyla seçmenin sürekli aynı olumsuz duygu durumuna maruz bırakılması davranışlarının da kestirilememesi durumunu ortaya çıkarmaktadır. Fakat parti aidiyeti yüksek bir kişi için ise her zaman savunulan görüşe yatkın olmayı beraberinde getirebilmektedir. Pozitif reklamcılık çalışmalarında ise bireylerin kendini daha rahat, mutlu, riskten uzak algılaması partiye yönelik olumlu duyguları arttırmaktadır. Bu sayede parti ile duygusal yakınlık kuran seçmen geçmişten gelen kodlarının da etkisi ile olumlu bir algılama sürecine girmektedir. Özellikle AK Partinin incelenen reklamlarında olumlu duygu öğesinin daha baskın olduğunu fakat yer yer olumsuz duyguları da uyaracak iletişim stratejisi geliştirdiğini söylemek mümkündür. CHP'nin yapmış olduğu reklamlarda ise iktidara ve iktidarın başarısızlıklarına karşı seçmende olumsuz duygu uyarılmasının sıklıkla yapıldığı ve ardından kendisini ön plana çıkararak olumlu duygu hareketliliği sağladığı görülmüştür. Ayrık duygu modelinde de belirtildiği üzere insanlar kültürel fark olmaksızın benzer olumlu ve olumsuz duygulara sahiptir. Biyolojik bir süreci ifade eden bu durum, seçmenin odak noktasını etkilemede her iki duygu öğesinin de siyasiler tarafından kullanılmasına işaret etmekte ve bütünleşik bir siyasal iletişim kurgusuna atıfta bulunmaktadır.

\section{SONUÇ}

Siyasetin doğrudan belli bir hedef kitleye ulaşmasında iletişim, siyasetin temel bir aracı olarak konumlanmaktadır. Siyaset ve iletişim ilişkisinin bağımlı bir süreç olması, seçmen davranışlarına nüfuz etmede oldukça önemli bir bütünlük oluşturmaktadır. Genel iletişim sürecinde belirtildiği gibi kaynak; bilgi, enformasyon ve duygu yüklü sözcüklerle mesaj stratejisini oluşturmakta ve herhangi bir iletişim kanalını kullanarak bu mesajı hedef kitleye ulaştırmaktadır. Seçmen kitlesini ikna etmek, tutumlarına etki etmek amacıyla birçok iletişim stratejisi geliştiren siyasi liderler, nihayetinde seçmende davranış değişikliği oluşturmak amacıyla farklı ikna tekniklerine başvurmaktadır. Bu sebeple çalışmada özellikle duygu, duyguların bilişsellik ile ilişkisi ele alınarak rasyonel karar alma tercihlerine nasıl etkide bulunduğu literatür boyunca açılanmaya çalışılmıştır. Duyguların zihnin çimentosu olması yapılan siyasal iletişim kampanyalarında duygunun da her zaman temel merkezde tutulduğunu göstermektedir. İnsan sadece mantıksal düşünen bir varlık değil, aynı zamanda duygusal düşünme yapısı ile de davranış geliştiren bir 
varlıktır. Bu işlevlerin gerçekleştiği temel merkez ise beyinde yer almaktadır (Tan, 2021, s. 24). Beynin önemli noktaları arasında yer alan sağ beyin ve sol beyin ayrımı beynin mantıksal ve duygusal karar alma süreçlerini açıklamada önemli bir rol oynamaktadır. Yapılan araştırmalara göre sol beyin analitik ve mantık çerçevesi ile eş tutulurken, sağ beyin ise sezgisel ve duygusal düşünme yöntemi ile eş tutulmaktadır. Bu sebeple mantık ve duygu ikilemi davranışın açıklanmasında önemli karar vericiler olarak konumlanmaktadır (Tan, 2021, s. 31-33). Siyasilerin beynin duygusal hareket eden bir tasarımla da var olduğunu bilmesi, siyasal iletişim stratejilerinin önemli bir parçasını oluşturmaktadır. Bu şekilde insanlar bir gruba ait olarak ideolojik davranışlarının yönlendirilmesine açık bir hale gelmektedir (Erdem \& Batı, 2016, s. 317-319). Dolayısıyla siyasetçilerin duyguların önemini bilmesi, eski beyni tanıması ve rasyonel değerlendirme ile değil duygusal değerlendirme ile hareket etmeye meyil göstermesi gönderilen mesaj stratejisinin etkisini de güçlendirmektedir.

Özellikle son dönemde yapılan araştırmalar siyasal kampanyalarda duyguların yoğun olarak kullanıldığını göstermektedir. Negatif ve pozitif etkiler doğrultusunda ele alınan duygular, siyasiler tarafından korku, coşku, öfke, gurur, hüzün, mutluluk, umut, birlik, kardeşlik, saygınlık gibi duygular uyarılarak kullanılmaktadır. Hem geleneksel hem de yeni medya üzerinden gerçekleştirilen bu siyasal kampanyalar siyasi tanıtımı başarıya ulaştırmada aktif olarak kullanılmaktadır. Çalışma içerisinde incelenen siyasal reklamlarda duygusal çekiciliklerin, "özellikle seçmenlerin dikkatini çekmek, seçmenleri mobilize etmek, oy vermeye yönlendirmek, seçmenlerin siyasal aktivite düzeylerini artırmak ya da seçmenleri rakip partilerden uzaklaştırmak" için kullanıldığı görülmektedir (Akt. Ateş, 2016, s. 86).

Çalışma içerisinde incelenen ve AK Parti'ye ait olan "Zümrüdü Anka Türkiye Vakti AK Parti" ve "Millet Eğilmez Türkiye Yenilmez" reklamları incelenmiştir. Reklam içerisinde özellikle odaklanılan duygusallık öğelerinin kardeşlik, birlik, beraberlik, heyecan, coşku, hüzün ve korku olduğu görülmektedir. Ayrıca AK Parti, Osmanlıdan günümüze dek hikâye anlatıcılığını ön planda tutarak metne şiirsellik katmış ve bu sayede seçmen ile duygusal bir bağ kurmuştur. Yine iki reklam filminde de müzik unsuru şiirle senkron bir şekilde seçmene sunularak, seçmeni duygusal olarak motive etmek hedeflenmiştir. AK Parti'nin belirtilen iki reklam örneği iktidarın millet için çalıştığını vurgulamakta ve yer yer dini öğelerle de seçmenin bilinçaltına nüfuz edilerek özdeşleşme sağlanmaktadır. 
CHP'nin yapmış olduğu "Milletçe Alkışlıyoruz" ve "Gelin Oy Verin Gitsinler!" reklamları ise incelenen diğer reklamlardır. Bu reklamlarda iktidar hedef alınarak öncelikle seçmende iktidara karşı olumsuz duygular uyarılmış daha sonra da tüm bu sıkıntıları aşabilecek bir parti olarak CHP seçmene alternatif parti olarak sunulmuştur. Negatif reklamcılık grubunda ele alınabilen bu reklamlar seçmende kızgınlık, öfke, stres ve sıkışmışık hissi oluştururken diğer taraftan da umut, heyecan ve coşku gibi duyguları uyarmaktadır. Yine CHP'nin yapmış olduğu reklamlarda korku çekiciliğinin yoğun olarak kullanıldığı gözlemlenmektedir.

Korku unsurunun iletişim kampanyalarında sıklıkla kullanılması seçmende beynin uyarılmasını beraberinde getirirken, oluşturulan herhangi bir tehdit durumuna karşı önlem alma duygusunu da aktive etmektedir. Bunun yanında öfke duygusunun iletişim stratejilerinde kullanılması, seçmenin birdenbire karar vermesini sağlayarak ümitsiz bir davranış sergilemesine sebep olmaktadır. Yine negatif duygu grubunda yer alan hüzün ise seçmenin var olan duruma karşı memnuniyetsiz bir hisse kapılmasına sebep olurken bir duruma karşı seçmende bir suçlu arama psikolojisini tetiklemektedir. Yine coşku, heyecan, gurur gibi duyguların uyarılması seçmenin motivasyonunu arttırmakta ve var olan politik davranışını sürdürmesini teşvik etmektedir (Akt. Ateş, 2016, s. 88-91). Bu bağlamda çalışma içerisinde sunulan bilgilerin hem seçmene hem de siyasilere önemli veriler sunması beklenmektedir. Bunun yanı sıra bu çalışmanın ileride yapılacak olan siyasal iletişim ve duygu çalışmalarına da yol göstermesi olasıdır.

\section{EXTENDED ABSTRACT}

Today, political leaders affect voter behavior with both rational and emotional communication strategies. It is scientifically proven that not only rational factors but also emotional factors are highly functional in voters' decision making processes. Although the idea of using voter feelings in favor of the government goes back to ancient times, many scientific researches on the human brain have deepened the use of these strategies in different areas.

The need for political information such as political parties, leaders, message strategies, promises, and party programs has an important place in forming the opinions of the voters while making decisions. The creation of all this information needed by the voter with a certain persuasion strategy reveals the importance of rational and emotional message strategies. In the political communication strategies to be formed in this sense, the voter's attitude, cognitive map and belief systems are among 
the basic components used in encoding the emotional message. According to some opinions, although it is stated that the voters actively use the rational decision-making mechanism in political decisionmaking processes, studies on emotion reveal that this situation occurs in a more priority way. Besides, the fact that the voter is not always able to evaluate the information correctly shows that he/she acts with her feelings and reactions. One of the main reasons why individuals cannot make decisions with completely rational choices; Basic factors such as culture, past experiences, environmental conditions, socio-economic level, social norms and rules, power structure show that a lot of data coexist in decisionmaking choices. The fact that these factors affect the phenomenon area of the individual naturally causes his/her to not evaluate the political decision-making processes in a completely rational way.

Emotions, which are considered as the sixth of human sense, reveal the role and power of mass media in influencing voters. Mass media, which is the focal point of political communication, also develops and transforms the techniques and methods of election campaigns. In this context, the fact that political leaders reach the voters directly through mass media requires their reflection on the message strategies in the social transformation. For this reason, the changes in the emotional dimension of the individual, which are also discussed within the subject, are followed in social activeness and political communication strategies are also designed. Throughout the study, it is revealed in both the literature and the research part that emotion affects the voter as much as the rational decision-making process. As seen in the political advertisements within the study, it is observed that the most coded emotional messages aim to reveal certain emotional loads in individuals and aim to achieve success in this way.

In this study Ak Parti and CHP advertisements were analyzed. When the findings are evaluated, it is possible to say that voters are faced with emotional-intensive political advertisements and this situation also affects their decision-making processes. Both the AK Party and the CHP aim to influence the target voters with their election activities, which reveal feelings towards the voters. It is possible to say that the positive emotion element is more dominant in the advertisements of the AK Party, but it has developed a communication strategy that will occasionally stimulate negative emotions. In the advertisements of the CHP, it was seen that negative emotions were frequently stimulated in the voters against the government and the failures of the government, and then it brought positive emotional 
mobility by bringing itself to the forefront. It is also supported by the literature review that negative advertising examples that reveal the risk perception as a result of the analyzes made the voters think and make the decision repeatedly questioned. However, it cannot be said that negative advertisements that clearly reveal the perception of risk and threat are always successful in changing voter behavior. The main reason why risk is not rationalized is that the government party has a clear attitude towards risks. The stimulation of the risk perception in the individual sometimes causes the individuals to make a decision that is far from rational, with the increase of uncertainty. In particular, the stimulation of feelings such as constant anger and fear in the electorate stimulates the endocrine gland in the nervous system of the individual and causes the body to release adrenaline. Since the blood in the body of an angry person is transferred to a different organ, the brain cannot function routinely enough and cannot make a rational decision. Therefore, the voter is constantly exposed to the same negative emotional state, which reveals that his/her behavior cannot be predicted.

\section{KAYNAKÇA}

Aksoy, i. U. (2019). Uluslararası politika akademisi / 2018 genel seçimleri öncesi AK Parti'nin siyasi reklamlarının incelenmesi: Zümrüdüanka reklam filminin alımlanması örneği. 01 15, 2021 tarihinde http://politikaakademisi.org/2019/06/18/2018-genel-secimleri-oncesi-ak-partininsiyasi-reklamlarinin-incelenmesi-zumruduanka-reklam-filminin-alimlanmasi-ornegi/ adresinden alındı

Aristoteles. (1997). Retorik. İstanbul: Yapı Kredi Yayınları.

Ateş, S. (2016). Siyasal reklamlarda duygusal çekicilik kullanımı: 7 Haziran 2015 genel seçimlerinde siyasal partiler tarafından üretilen reklam filmlerinin analizi. Karadeniz Teknik Üniversitesi Illetişim Araştırmaları Dergisi, s. 85-103.

Aydın, A., Araz, A., \& Asan, A. (2011). Görsel analog ölçeği ve duygu kafesi: Kültürümüze uyarlama çalışması. Türk Psikoloji Yazıları, s. 1-13.

Aziz, A. (2019). Siyasal iletişim. Ankara: Nobel Yayıncılık.

Bakker, B., Schumacher, G., \& Roodijn, M. (2020). Hot politics? affective responses to political rhetoric. American Political Science Review, s. 1-15.

Balcı, Ş., \& Bal , E. (2008). 22 Temmuz 2007 genel seçimleri'nde AKP ve CHP reklamları: Karşılaştırmalı bir analiz. İstanbul Üniversitesi Iletişim Fakültesi Dergisi, s. 5-28.

Barış, Ö. (2018). Siyasal reklamcılık alanında göstergebilimsel bir inceleme: Adalet ve kalkınma partisi 24 Haziran zümrüd-ü anka seçim reklamı örneği. Ecider, s. 52-64.

Barrett, L., \& Russell, J. (1999, 02 01). The structure of current affect: Controversies and emerging consensus. American Psychological Society, s. 10-14. 
Batı, U. (2017). Beynimizin ve kararlarımızın sıradışı hikayesi sinaps. İstanbul: Doğan Kitap.

Batı, U. (2018). İkna, manipülasyon, cehalet ve şeytanın pabucundaki beyin. Youtube: https://www.youtube.com/watch?v=jHfr2xnfd40 adresinden alındı

Batı, U. (2020). Kusursuz kararlar vermek ve ikna sanatı. İstanbul: Doğan Egmont Yayıncılık ve Yapımcilık.

Baykal, D. (1970). Siyasal katılma bir davranış incelemesi. Ankara: Ankara Üniversitesi Siyasal Bilgiler Fakültesi Yayınları.

Cottam, M., Mastors, E., Preston, T., \& Beth, D. (2017). Siyaset psikolojisine giriş. Ankara: BB101 Yayınları.

Cömert, N. Ç. (2019). Siyasal iletişimde le bonyen model. İstanbul: Filiz Kitabevi.

Damasio, A. (2018). Spinoza'yı ararken. Ankara: Odtü Yayıncılık.

Descartes, R. (2013). Ruhun ihtirasları. İstanbul: Sayfa Yayınları.

Doğan, A. (2015). Siyasal reklamlarda "millet" teması: "Cumhurbaşkanlığı seçimi ve 30 Mart yerel seçimi örneği". International Periodical For The Languages, Literature and History of Turkish or Turkic, s. 249-268.

Doğan, A., \& Aslantaş , A. (2015). Bir ikna yöntemi olarak siyasal reklamlarda millet ve hizmetin temsili. Akademik Bakış Dergisi, s. 35-52.

Erdem, O., \& Batı, U. (2016). Ben bilmem beynim bilir! İstanbul: MediaCat Yayınları.

Erdinç, İ. E. (2012). Üniversite öğrencilerinin oy verme davranışlarında etkili olan faktörlere yönelik bir araştırma. Karadeniz Teknik Üniversitesi Iletişim Araştırmaları Dergisi, s. 55-70.

Erdoğan, S. (2016). Duygusal yüz ifadelerinin ve uyarıcı sunum süresinin zaman algısına etkisi. Doktora Tezi. Ankara: Hacettepe Üniversitesi Sosyal Bilimler Enstitüsü, Psikoloji Anabilim Dalı, Genel Psikoloji Bilim Dalı.

Gabriel, O., \& Westle, B. (2012). Wählerverhalten in der demokratie: Eine einführung. Germany: Nomos Verlagsgesellschaft.

Goleman, D. (2004). Duygusal zeka. İstanbul: Varlık Yayınları.

Gökçe, G. (2019). Edebiyat, tarih, siyaset ve psikoloji kavşağında bir alman'ın hikayesi: Korku iklimi örneği. Pivolka, 1-4.

Göksu, O. (2019). Ak Parti'nin seçim stratejileri ve siyasal kampanyaları: 2002-2014 dönemi analizi. Turkish Studies, s. 589-621.

Göksu, O., \& Özkoyuncu, F. (2015). 7 Haziran 2015 genel seçimlerinde CHP'nin seçim kampanyasının temelleri, söylemi ve iktidar uygulamaları. A. Özkan içinde, Siyasetin Iletişim Odağı; Seçim Kampanyaları (s. 111-205). Konya: Eğitim Yayınevi.

Güllüpunar, H. (2010). Siyasal iletişim ve aday imajı. Konya: Eğitim Akademi.

İsen, G., \& Batmaz, V. (2006). Ben ve toplum. İstanbul: Salyangoz Yayınları. 
Karataş, Z. (2015). Sosyal bilimlerde nitel araştırma yöntemleri. Manevi Temelli Sosyal Hizmet Araştırmaları Dergisi Cilt 1, Sayı 1.

Kılıç, Ş. (2020). Duygu sosyalleştirme kuramdan araştırmaya. Ankara: Pegem Akademi.

Kuppens, P., Ceulemans, E., Timmerman, M., \& Diener, E. (2006). Universal intracultural and intercultural dimensions of the recalled frequency of emotional experience. Journal of CrossCultural Psychology, s. 491-515.

Machiavelli, N. (2018). Prens. Ankara: Dorlion Yayınları.

Marcus, G. (1991). Emotion and politics: hot cognitions and the rediscovery of passion. SAGE, London, $195-232$.

Marcus, G., Neuman, R., \& Keele, L. (2007). The third way: The theory of affective intelligence and american democracy. Chicago and London: The University of Chicago Press.

Marques, J., Dominic , A., \& Paez, D. (2008). Social categorization, social identification, and rejection of deviant group members. 12 26, 2020 tarihinde ResearchGate:

https://www.researchgate.net/publication/37626446_Social_Categorization_Social_Identific ation_and_Rejection_of_Deviant_Group_Members adresinden alındı

Massumi, B. (2018). Duygu politikası. İstanbul: Otonom Yayıncılık.

Maxwell, J. C., \& Dornan , J. (2002). Etkili insan olmak. İstanbul: Sistem Yayıncılık.

Morin, C., \& Renvoise , P. (2019). Beyindeki ikna kodu. İstanbul: Maltepe Üniversitesi Kitapları.

Neuman, W. (2014). Social research methods: Qualitative and quantitative approaches. Essex: Pearson Education Limited.

Okmeydan, C. K. (2018). 24 Haziran 2018 seçimlerinde seçmenler tarafından en çok ilgi gören siyasal reklamlar üzerine bir inceleme. Political Communication in Theory and Practice (s. 41-60). Aydın: Non-Western Approaches ISBN: 978-975-8254-77-4 Proceeding Book 2018.

Oskay, Ü. (1982). XIX. yüzyıldan günümüze kitle iletişiminin kültürel işlevleri kuramsal bir yaklaşım. Ankara: Ankara Üniversitesi Siyasal Bilgiler Fakültesi Yayınları.

Oskay, Ü. (2017). İletişimin abc'si. İstanbul: İnkilap Kitabevi.

Özdemir, M. (2010). Nitel veri analizi: Sosyal bilimlerde yöntembilim sorunsalı üzerine bir çalışma. Eskişehir Osmangazi Üniversitesi Sosyal Bilimler Dergisi.

Özkan, A. (2015). Siyasal iletişim yönetici: Seçim kampanyası, siyasal reklam ve iletişim stratejileri. Siyasetin iletişim odağı seçim kampanyaları (s. 7-29). içinde Konya: Eğitim Yayınevi.

Özkan, A. (2016). 7 Haziran ve 1 Kasım seçimlerinde siyasal iletişim. Seta, 7-30.

Scarantino, A. (2017). Emotion researcher. ISRE's Sourcebook for Research on Emotion and Affect, 2-3.

Smith, T. W. (2018). Duygular sözlüğü. İstanbul: Kolektif Kitap.

Solms , M., \& Turnbull, O. (2015). Beyin ve iç dünya öznel deneyimin sinirbilimine giriş. İstanbul: Metis Yayınları. 
Szanto, T., \& Slaby, J. (2020). Political emotions. The Routledge Handbook of Phenomenology of Emotions., $1-21$.

Tan, A., (2021). Bir bilgi kaynağı olarak duygu-akıl ilişkisi, Atlas Ulusal Hakemli Sosyal Bilimler Dergisi, 21-46.

Tolle, E. (2001). Şimdi'nin gücü. İstanbul: Akaşa Yayınları.

Utych, S. M. (2018). Negative affective language in politics. American Politics Research, s. 77-102.

Uztuğ, F. (2003). Siyasal marka konumlandırma ve siyasal mesaj stratejileri ilişkisi: 1991-1995-1999 seçimleri türk siyasal reklam mesaj türleri analizi. Selçuk Iletişim Dergisi, 3(1), 4-19.

Uztuğ, F. (2009). Siyasal iletişimde hikaye ya da strateji: Efsaneler, gerçekler. A. Özkan içinde, Siyasetin iletişimi (s. 115-129). İstanbul: Tasam Yayınları.

Valentino, N., Brader, T., Groenendyk, E., Gregorowicz, K., \& Hutchings, V. (2011). Election night's alright for fighting: The role of emotions in political participation. The Journal of Politics, 156-170.

Vodinalı, S., \& Çötok, N. (2015). Siyasal propoganda bağlamında siyasal reklamlar: 2015 Türkiye genel seçimlerinde AKP/CHP/MHP partileri tv reklamları üzerine bir değerlendirme. Global Media Journal TR Edition, 497-531.

Yilmaz, T., \& Bekaroğlu, E. (2020). Ayrık duygular ölçeğinin türkçeye uyarlama, güvenirlik ve geçerlik çalışması. Turkish Studies, 2232-2244.

Youtube. (2018). Zümrüdü anka - Türkiye Vakti. https://www.youtube.com/watch?v=rSTkxC-D4Do adresinden alındı (2021, 02 23).

Youtube. (2014). Millet eğilmez. https://www.youtube.com/watch?v=80J0FCe69to: https://www.youtube.com/watch?v=80J0FCe69to adresinden alındı (2021, 02 23).

Youtube. (2015). Milletçe alkışlıyoruz. https://www.youtube.com/watch?v=JFdXMtQ2qBw adresinden alındı $(2021,02$ 23)

Youtube. (2015). Oy verin, gitsinler! https://www.youtube.com/watch?v=ITFFNcITzkg adresinden alındı (2021, 02 23).

Zeybek, B. (2020). Mitinglerde siyasal retroiğin kullanımı: 24 Haziran 2018 cumhurbaşkanlığı seçimleri. Intermedia International e-Journal, 190-203. 